\title{
Article $\beta$-Galactosidase-Producing Isolates in Mucoromycota:
Screening, Enzyme Production, and Applications for
Functional Oligosaccharide Synthesis
}

\author{
Bettina Volford ${ }^{1}\left(\mathbb{D}\right.$, Mónika Varga ${ }^{1}$, András Szekeres ${ }^{1}{ }^{\circledR}$, Alexandra Kotogán ${ }^{1}$, Gábor Nagy ${ }^{1,2}{ }^{\oplus}$, \\ Csaba Vágvölgyi ${ }^{1}{ }^{1}$, Tamás Papp ${ }^{1,2}$ and Miklós Takó ${ }^{1, *}$ \\ 1 Department of Microbiology, Faculty of Science and Informatics, University of Szeged, Közép fasor 52, \\ H-6726 Szeged, Hungary; bettina.volford86@gmail.com (B.V.); varga.j.monika@gmail.com (M.V.); \\ szandras@bio.u-szeged.hu (A.S.); primula15@gmail.com (A.K.); nagygab86@gmail.com (G.N.); \\ csaba@bio.u-szeged.hu (C.V.); pappt@bio.u-szeged.hu (T.P.) \\ 2 MTA-SZTE “Lendület” Fungal Pathogenicity Mechanisms Research Group, University of Szeged, \\ Közép fasor 52, H-6726 Szeged, Hungary \\ * Correspondence: tako78@bio.u-szeged.hu; Tel.: +36-62-544-516
}

Citation: Volford, B.; Varga, M.; Szekeres, A.; Kotogán, A.; Nagy, G.; Vágvölgyi, C.; Papp, T.; Takó, M. $\beta$-Galactosidase-Producing Isolates in Mucoromycota: Screening,

Enzyme Production,

and Applications for Functional Oligosaccharide Synthesis. J. Fungi 2021, 7, 229. https://doi.org/ $10.3390 /$ jof7030229

Academic Editors: Thomas Edison E. dela Cruz and Fahrul Huyop

Received: 5 February 2021

Accepted: 17 March 2021

Published: 19 March 2021

Publisher's Note: MDPI stays neutral with regard to jurisdictional claims in published maps and institutional affiliations.

Copyright: (c) 2021 by the authors. Licensee MDPI, Basel, Switzerland. This article is an open access article distributed under the terms and conditions of the Creative Commons Attribution (CC BY) license (https:/ / creativecommons.org/licenses/by/ $4.0 /)$.

\begin{abstract}
Galactosidases of Mucoromycota are rarely studied, although this group of filamentous fungi is an excellent source of many industrial enzymes. In this study, 99 isolates from the genera Lichtheimia, Mortierella, Mucor, Rhizomucor, Rhizopus and Umbelopsis, were screened for their $\beta$-galactosidase activity using a chromogenic agar approach. Ten isolates from the best producers were selected, and the activity was further investigated in submerged (SmF) and solid-state (SSF) fermentation systems containing lactose and/or wheat bran substrates as enzyme production inducers. Wheat bran proved to be efficient for the enzyme production under both SmF and SSF conditions, giving maximum specific activity yields from 32 to $12,064 \mathrm{U} / \mathrm{mg}$ protein and from 783 to $22,720 \mathrm{U} / \mathrm{mg}$ protein, respectively. Oligosaccharide synthesis tests revealed the suitability of crude $\beta$-galactosidases from Lichtheimia ramosa Szeged Microbiological Collection (SZMC) 11360 and Rhizomucor pusillus SZMC 11025 to catalyze transgalactosylation reactions. In addition, the crude enzyme extracts had transfructosylation activity, resulting in the formation of fructo-oligosaccharide molecules in a sucrose-containing environment. The maximal oligosaccharide concentration varied between 0.0158 and $2.236 \mathrm{~g} / \mathrm{L}$ depending on the crude enzyme and the initial material. Some oligosaccharideenriched mixtures supported the growth of probiotics, indicating the potential of the studied enzyme extracts in future prebiotic synthesis processes.
\end{abstract}

Keywords: extracellular $\beta$-galactosidase; zygomycetes; activity screening; fermentation; transgalactosylation; transfructosylation; functional oligosaccharides; probiotics

\section{Introduction}

$\beta$-Galactosidases ( $\beta$-D-galactoside galactohydrolase or lactase, EC 3.2.1.23) are important biocatalysts in many food and pharmaceutical applications, as they can catalyze both the hydrolysis and synthesis of glycosides affecting human health. For instance, $\beta$ galactosidases are frequently used to produce lactose hydrolyzed foods through the degradation of lactose to galactose and glucose monomers in the dairy industry [1]. These special food products are beneficial for people with low intestine $\beta$-galactosidase levels that causes the condition of lactose intolerance. The hydrolyzing activity of $\beta$-galactosidases is utilized in various other applications, such as prevention against lactose-related crystallization in frozen foods and condensed milk, or ethanol and sweet syrup production from whey lactose [2].

$\beta$-Galactosidases can synthesize galacto-oligosaccharide (GOS) and lactulose-derived GOS (OsLu) molecules through the enzymatic transgalactosylation of lactose and lactulose, 
respectively. The biosynthesis of these molecules is interesting, both in health and technological perspectives [3]. GOS and OsLu are non-digestible carbohydrates and serve as fermentable substances for beneficial gut microorganisms. They can stimulate the growth and/or activity of probiotics, including Lactobacillus and Bifidobacterium strains [4,5]. Practically, GOSs can be used in the development of prebiotic and bifidogenic food and beverage ingredients in the food technology as well as in the treatment of certain gastrointestinal disorders [6,7], which is also supported by their low caloric value and high stability at a wide range of $\mathrm{pH}$ and temperature [8]. Taken together, the discovery of new $\beta$-galactosidases from natural sources and/or by using metagenomic approaches, and characterization of their hydrolytic and synthetic capabilities are efficient ways to provide valuable catalysts for future glycobiology research [3].

Most commercial $\beta$-galactosidases are derived from bacteria, yeasts and filamentous fungi [9]. The production of the enzyme protein can be conducted using such organisms due to the possibility of mass cultivation, mild fermentation conditions as well as the easy elaboration of optimized production systems. In addition, many microorganisms, especially filamentous fungi, can grow well on low-cost media such as agro-industrial byproducts and utilize them to produce $\beta$-galactosidases in high amounts. The production and characterization of $\beta$-galactosidases have been extensively studied in fungi [2,9], and even the GOS synthesis has been evaluated in detail for many enzymes [6,10-12]. Mucoromycota fungi (i.e., members of the former Zygomycota), however, have been given less attention in this regard, although these microorganisms are good sources of many industrial enzymes, such as lipases, hydroxylases, phytases and a set of various carbohydrate cleaving biocatalysts [13]. To our knowledge, there are only some examinations dealing with extracellular $\beta$-galactosidases in this filamentous fungal group. These works mainly focused on enzyme activities from Rhizomucor isolates [14-17], but an effective producer Mucor sp. isolate has also been described by Silvério et al. [12].

Submerged fermentation $(\mathrm{SmF})$ conditions are frequently used for $\beta$-galactosidase production by fungi. Excellent supports to achieve high enzyme yield in liquid conditions are lactose, skim milk and other materials that contain $\beta$-galactosyl linkage between some of their molecules. However, a number of studies have highlighted the relevance of the solid-state fermentation (SSF) approach on agrowaste substances, e.g., wheat bran and straw, rice bran and straw, sugarcane bagasse and pomegranate peel, for large scale $\beta$-galactosidase production in fungi [17-20].

In the present study, the $\beta$-galactosidase activity of Mucoromycota strains belonging to the order Mucorales and Mortierellales was evaluated and compared through a visually detectable chromogenic agar assay. The research included investigations on the enzyme production in both SmF and SSF conditions, as well as a comprehensive analysis on the oligosaccharide synthesis capacity of selected $\beta$-galactosidase-active crude extracts. Finally, the effect of oligosaccharide-enriched cocktails produced enzymatically on the growth of probiotic microorganisms was also investigated.

\section{Materials and Methods}

\subsection{Microorganisms}

The fungal and bacterial strains used in this study were obtained from the Szeged Microbiological Collection (Szeged Microbiological Collection (SZMC), Szeged, Hungary; http:/ /www.wfcc.info/ccinfo/collection/by_id/987, accessed on 4 February 2021).

Fungal isolates of the genera Lichtheimia, Mortierella, Mucor, Rhizomucor, Rhizopus and Umbelopsis were subjected to the $\beta$-galactosidase activity screening test (Table S1). Strains with the highest activity were selected and used for further enzyme production and activity studies. Before each experiment, the fungi were grown on malt extract medium $(20 \% \mathrm{v} / \mathrm{v}$ malt extract, $50 \mathrm{~mL} / \mathrm{L}$; yeast extract, $5 \mathrm{~g} / \mathrm{L}$; glucose, $5 \mathrm{~g} / \mathrm{L}$; agar, $20 \mathrm{~g} / \mathrm{L})$ for $5-10$ days at 20,25 or $37^{\circ} \mathrm{C}$, depending on the culturing requirements of the applied strain. To prepare the spore suspension, a volume of $5 \mathrm{~mL}$ of distilled water was added to each 
slant. After vortexing, the sporangiospore number was set by serial dilution in distilled water followed by counting in a Bürker chamber under a light microscope.

The probiotic strains selected for growth-promoting activity assays were Lactobacillus casei SZMC 23430, Lactobacillus acidophilus LA-5 SZMC 23432, Bifidobacterium animalis subsp. lactis BB-12 SZMC 26956 and Saccharomyces boulardii CNCM I-745 SZMC 26957. Strains were maintained on de Man, Rogosa and Sharpe (MRS) agar (VWR, Debrecen, Hungary) at $37^{\circ} \mathrm{C}$. Before the assay, fresh cultures were prepared through cultivation in $30 \mathrm{~mL}$ of MRS broth (VWR) for $24 \mathrm{~h}$ at $37^{\circ} \mathrm{C}$ under oxygen-depleted conditions generated by an Anaerocult $C$ system (Merck, Budapest, Hungary) in a cultivation jar.

\subsection{Chromogenic Agar Test for $\beta$-Galactosidase Activity Screening}

A chromogenic method was used to screen the fungi for their $\beta$-galactosidase activity in Petri plate incubation. The growth medium contained $20 \%(v / v)$ malt extract $(20 \mathrm{~mL} / \mathrm{L})$, lactose $(20 \mathrm{~g} / \mathrm{L})$, peptone $(1 \mathrm{~g} / \mathrm{L})$ and agar $(20 \mathrm{~g} / \mathrm{L})$. After sterilization, the medium was supplemented with $0.5 \%(v / v)$ of 5 -bromo-4-chloro-3-indolyl- $\beta$-D-galactopyranoside $(X-$ gal; Thermo Fisher Scientific, Waltham, USA) solution $(20 \mathrm{mg} / \mathrm{mL}$ in dimethyl-sulfoxide). A volume of $20 \mu \mathrm{L}$ of spore suspension $\left(10^{6}\right.$ spores $\left./ \mathrm{mL}\right)$ was added to each agar plate and the cultures were incubated for 10 days at temperatures depending on the culturing requirements of the tested fungus. Visual detection of the plates was performed daily, and the level of the $\beta$-galactosidase production was evaluated from the intensity of the blue color developed. The categories of no blue color (NC), light blue color $(+)$, darker blue color $(++)$, blue color $(+++)$, dark blue color $(++++)$ and deep dark blue color $(+++++)$ were defined to evaluate the chromogenic test. Three biological replicates were performed with each tested strain. The qualitative chromogenic assay serves as a preliminary test to screen for enzyme production as reported in other similar studies [12,21-24].

\section{3. $\beta$-Galactosidase Production in Submerged and Solid Cultures}

For SmF tests, $20 \mu \mathrm{L}$ of sporangiospore suspension $\left(10^{6}\right)$ was transferred to $100-\mathrm{mL}$ Erlenmeyer flasks containing $30 \mathrm{~mL}$ of growth medium (in $\mathrm{g} / \mathrm{L}$ : peptone 4, yeast extract 4, $\mathrm{KH}_{2} \mathrm{PO}_{4} 2, \mathrm{Na}_{2} \mathrm{HPO}_{4}{ }^{*} 12 \mathrm{H}_{2} \mathrm{O} 8, \mathrm{MgSO}_{4}{ }^{*} 7 \mathrm{H}_{2} \mathrm{O}$ 0.25) supplemented with lactose or lactose and wheat bran in a concentration of $20 \mathrm{~g} / \mathrm{L}$. Incubation was performed under continuous shaking (200 rpm) for 7 days at 20,25 or $37^{\circ} \mathrm{C}$. A volume of $1 \mathrm{~mL}$ samples were taken immediately after the inoculation and on the $2 \mathrm{nd}, 4$ th, and 7 th days of fermentation. Then, the samples were centrifuged at $16,200 \times g$ for $20 \mathrm{~min}$ and the supernatant diluted in sodium acetate buffer ( $50 \mathrm{mM}, \mathrm{pH} 6.0)$ was used to determine the $\beta$-galactosidase activity and the protein content.

The SSF was carried out in 250-mL Erlenmeyer flasks containing $5 \mathrm{~g}$ of wheat bran and $1 \mathrm{~g}$ of soy flour moistened with $5 \mathrm{~mL}$ of distilled water. After sterilization, the flasks were inoculated with $20 \mu \mathrm{L}$ of sporangiospores $\left(10^{6}\right)$ and incubated for 7 days at 20,25 or $37^{\circ} \mathrm{C}$. Sampling was scheduled as the same as to that applied in the liquid culture tests. Corresponding flasks were taken at predetermined intervals, and the fermented medium was extracted with $30 \mathrm{~mL}$ of sodium acetate buffer ( $50 \mathrm{mM}, \mathrm{pH}$ 6.0) by incubating the extract at $4{ }^{\circ} \mathrm{C}$ for $4 \mathrm{~h}$. The extracts were then filtered through a gauze, and a $1 \mathrm{~mL}$ sample was taken from the filtrate and centrifuged at $16,200 \times g$ for $20 \mathrm{~min}$. Then, the supernatant was stored at $-20{ }^{\circ} \mathrm{C}$ until the $\beta$-galactosidase activity and total protein concentration assays. The samples were diluted in sodium acetate buffer $(50 \mathrm{mM}, \mathrm{pH}$ 6.0) before the measurements. All fermentation tests were carried out in three independent experiments.

\section{4. $\beta$-Galactosidase Activity Assay}

$\beta$-Galactosidase activity was determined by incubating $180 \mu \mathrm{L}$ of diluted samples at $50{ }^{\circ} \mathrm{C}$ for $30 \mathrm{~min}$ with $20 \mu \mathrm{L}$ of $7 \mathrm{mM}$ o-nitrophenyl- $\beta$-D-galactopyranoside ( $o \mathrm{NPG}$; Sigma-Aldrich, Munich, Germany) solution prepared in sodium acetate buffer ( $50 \mathrm{mM}$, $\mathrm{pH}$ 6.0). The reaction was stopped by adding $50 \mu \mathrm{L}$ of $100 \mathrm{mM}$ sodium carbonate, then the released o-nitrophenol was measured at $420 \mathrm{~nm}$ using a SPECTROstar Nano (BMG Labtech, 
Offenburg, Germany) microplate reader. A blank measurement was always performed before the incubation. The standard curve was set up from the absorbance data of the o-nitrophenol (Sigma-Aldrich) compound dissolved in sodium acetate buffer (50 mM, $\mathrm{pH}$ 6.0) in the concentration range of 20-200 $\mu \mathrm{M}$. One unit of enzymatic activity was defined as the amount of enzyme that liberated $1 \mu \mathrm{M}$ of $o$-nitrophenol per $1 \mathrm{~min}$ under the conditions of the assay.

\subsection{Determination of the Protein Content}

The total protein content in the culture filtrates and crude extracts was determined by using a Qubit Fluorometer (Invitrogen, Carlsbad, CA, USA) and the Quant-iT Protein Assay Kit (Invitrogen).

\subsection{Partial Purification of $\beta$-Galactosidases}

Seven-day-old cultures of wheat bran-based SSF were extracted by $30 \mathrm{~mL}$ of sodium acetate buffer ( $50 \mathrm{mM}, \mathrm{pH} 6.0)$, and after a 4 -h incubation at $4{ }^{\circ} \mathrm{C}$, the extracts were filtered through a gauze. To eliminate salts, low molecular weight sugars and other small molecules, a volume of $10 \mathrm{~mL}$ of each extract was filtrated through a Bio-Gel P-6 desalting cartridge (exclusion range 1 to $6 \mathrm{kDa} ; 50 \mathrm{~mL}$; Bio-Rad, Hercules, CA, USA), which was equilibrated with $50 \mathrm{mM}$ of sodium acetate buffer ( $\mathrm{pH}$ 6.0). Elution was performed with the same buffer at a flow rate of $9 \mathrm{~mL} / \mathrm{min}$, and the fraction containing $\beta$-galactosidase activity was collected.

\subsection{Gel Electrophoresis of Proteins}

Sodium dodecyl sulfate-polyacrylamide gel electrophoresis (SDS-PAGE) was performed on 12\% mini-Protean TGX gel (Bio-Rad) using NuPAGE MES running buffer (Invitrogen) according to the manufacturer's instructions. Protein bands were detected by staining the gels with $0.0025 \%$ Coomassie Brilliant Blue R-250.

\subsection{Enzymatic Synthesis Assay}

The synthesis of oligosaccharides was studied in four sets of reactions prepared in sodium acetate buffer ( $50 \mathrm{mM}, \mathrm{pH} 6.0)$ in a final volume of $2 \mathrm{~mL}$. These reaction conditions contained (i) $15 \%(w / v)$ lactose, (ii) $10 \%(w / v)$ skim milk ( $48 \% w / w$ lactose content, SigmaAldrich), (iii) $10 \%(w / v)$ lactose $+10 \%(w / v)$ fructose or (iv) $90 \mathrm{mM} o \mathrm{NPG}+10 \%(w / v)$ sucrose initial materials. A reaction mixture containing $20 \%(w / v)$ lactose and fructose was also prepared to examine the effect of the initial substrate concentration on product yield. After setting up the solutions, crude $\beta$-galactosidase corresponding to $2400 \mathrm{U}$ activity was added, and the mixtures were incubated at $50^{\circ} \mathrm{C}$ for $12 \mathrm{~h}$ under constant stirring (200 rpm). An enzyme-free sample of each reaction condition was used as the corresponding control. After incubation, the reaction mixtures were kept in boiling water for 5 min to stop the reaction. The samples were then cooled down to room temperature and stored at $-20{ }^{\circ} \mathrm{C}$ until the analytical measurements and growth-promoting activity tests. All enzymatic synthesis assays were performed in three biological parallels. The oligosaccharide yield was calculated using the following equation:

$$
\text { Oligosaccharide yield }(\%)=C_{1} / C_{0} \times 100
$$

where $\mathrm{C}_{0}$ and $\mathrm{C}_{1}$ are the initial concentration of the substrate (i.e., lactose, lactose content of skim milk or sucrose) and the concentration of oligosaccharides, respectively.

\subsection{HPLC-MS/MS Analysis of Carbohydrates}

The synthesized carbohydrates were analyzed by LC-MS/MS on a Nexera XR HPLC system (Shimadzu, Duisburg, Germany) coupled to a TSQ Quantum Access triple quadrupole mass spectrometer (Thermo Fisher Scientific) equipped with an H-ESI probe.

Liquid chromatographic separation was performed using a SeQuant ZIC-HILIC column $(3.5 \mu \mathrm{m}, 150 \times 2.1 \mathrm{~mm}$; Merck) equipped with a SeQuant ZIC-HILIC guard column 
$(20 \times 2.1 \mathrm{~mm})$ thermostated at $25^{\circ} \mathrm{C}$. The mobile phase A consisted of $5 \mathrm{mM}$ of ammonium acetate containing $0.1 \%$ formic acid, while acetonitrile containing $0.1 \%$ formic acid served as the mobile phase $\mathrm{B}$. The gradient elution was performed as follows: $0 \mathrm{~min}, 80 \% \mathrm{~B}$; $0.5 \mathrm{~min}, 80 \% \mathrm{~B} ; 8.5 \mathrm{~min}, 40 \% \mathrm{~B} ; 10.5 \mathrm{~min}, 40 \% \mathrm{~B} ; 11 \mathrm{~min}, 80 \% \mathrm{~B} ; 20 \mathrm{~min}, 80 \% \mathrm{~B}$. The flow rate of the mobile phase was maintained at $200 \mu \mathrm{L} / \mathrm{min}$ and the injection volume was $5 \mu \mathrm{L}$.

The general MS conditions were set as follows: spray voltage, $4500 \mathrm{~V}$; vaporizer temperature, $50{ }^{\circ} \mathrm{C}$; sheath gas (nitrogen) pressure, 50 psi; auxiliary gas (nitrogen) flow, 10 arbitrary units; ion transfer capillary temperature, $200^{\circ} \mathrm{C}$; collision gas (argon) pressure, 1.5 mTorr. Electrospray ionization was operated at negative mode. Mass spectrometric detection of the carbohydrates was carried out in selected reaction monitoring (SRM) mode. SRM transitions were $226.0>180.3,387.5>180.19,549.2>180.2$, and $711.2>383.5$ for mono-, di-, tri- and tetrasaccharides, respectively. The acquired data were processed using Xcalibur ${ }^{\mathrm{TM}}$ version 2.2.1 and Trace Finder version 3.3 (Thermo Fisher Scientific). Carbohydrate standards (glucose, fructose, galactose, sucrose, lactose, lactulose, raffinose, 1-kestose and nystose; Sigma-Aldrich) were used to analyze individual compounds in the reaction mixtures.

\subsection{Growth-Promoting Activity Assay}

A liquid culture approach was used to investigate the effect of oligosaccharideenriched samples on the growth of selected probiotics (see 2.1.). Half tubes containing $4 \mathrm{~mL}$ of $1 \%(w / v)$ skim milk solution, $900 \mu \mathrm{L}$ of distilled water and $100 \mu \mathrm{L}$ of reaction samples were inoculated with $100 \mu \mathrm{L}$ of fresh probiotics suspension prepared in MRS broth. Control cultures consisted of $5 \mathrm{~mL}$ of $1 \%(w / v)$ skim milk solution and $100 \mu \mathrm{L}$ of probiotics suspension (Control 1), or $4 \mathrm{~mL}$ of $1 \%(w / v)$ skim milk solution, $900 \mu \mathrm{L}$ of distilled water, $100 \mu \mathrm{L}$ of enzyme-free reaction sample and $100 \mu \mathrm{L}$ of probiotics solution (Control 2). The culturing tubes were then incubated for $24 \mathrm{~h}$ at $37^{\circ} \mathrm{C}$ under oxygen depleted conditions. Subsequently, a volume of $10 \mu \mathrm{L}$ from the cultures were inoculated equidistantly onto MRS agar medium prepared in Petri dishes. After drying, the plates were placed into an anaerobic jar and incubated at $37^{\circ} \mathrm{C}$ for $48 \mathrm{~h}$. Colonies were counted and the colony forming unit (CFU) was calculated by using the following equation:

$$
\mathrm{CFU} / \mathrm{mL}=\mathrm{A} \times 10^{n} \times 100
$$

where $\mathrm{A}$ is the number of the probiotic microorganism colonies counted and $n$ is the degree of dilution. Three biological replicates were performed with each sample tested.

\subsection{Statistical Analysis}

The results were calculated from at least two biological and three technical parallels and data were expressed as the means \pm standard deviation. Significance was calculated with a one-way analysis of variance (ANOVA) followed by Tukey's multiple comparison test in the GraphPad Prism 6.00 software (GraphPad Software Inc., San Diego, CA, USA). A $p$ value of $<0.05$ was considered as statistically significant. Pearson's correlation test in Microsoft 365 Excel was performed to investigate the association between the oligosaccharide concentration and the growth-promoting activity of samples.

\section{Results}

\subsection{Screening of $\beta$-Galactosidase Activity}

In this assay, the $\beta$-galactosidase activity of 99 fungal isolates from six Mucoromycota genera, namely Lichtheimia (18), Mortierella (16), Mucor (17), Rhizomucor (11), Rhizopus (20) and Umbelopsis (17), was screened. The cultivation of the strains on X-gal-containing medium was performed and the results were evaluated according to the intensity of blue color that developed on and around the colonies.

The enzyme production capacity varied within the tested fungi and there were notable differences in the activity between the strains from the same genus. Most strains with high activity were found among the Lichtheimia, Rhizomucor and Umbelopsis genera 
(Table S1). Representatives of Mortierella, Mucor and Rhizopus were generally less active, however, the Mortierella echinosphaera SZMC 11251, Mortierella globulifera SZMC 11209, Mucor plumbeus SZMC 12023 and all tested Rhizopus microsporus strains can be highlighted as effective $\beta$-galactosidase producers from these groups (Table S1). The activity data and origin of ten isolates identified as the best producers, namely Lichtheimia ramosa SZMC 11360, Lichtheimia corymbifera SZMC 11361, Lichtheimia hyalospora SZMC 11364, Rhizomucor miehei SZMC 11005, R. miehei SZMC 11014, Rhizomucor pusillus SZMC 11025, Rhizopus microsporus var. oligosporus SZMC 13619, M. echinosphaera SZMC 11251, Umbelopsis longicollis SZMC 11208 and Umbelopsis ramanniana var. angulispora SZMC 11234, and the temperature for their cultivation during the screening test were summarized in Table 1. A notable feature of most of these isolates was the high activity that appeared at the earlier stage of the incubation. After one-day cultivation, for instance, the R. miehei SZMC 11014 developed a visually well distinguishable blue color as compared to the other fungi. However, the activity of all the best producers reached a strong positive response if the later stage of incubation was considered (Table 1), and the blue color that developed turned to a deep dark at the 10th incubation day (Figure 1A-J).

Table 1. $\beta$-Galactosidase activity, cultivation temperature and origin of Mucoromycota isolates identified as the best producers in X-gal contained medium. The intensity of the blue color is proportional with the $\beta$-galactosidase activity.

\begin{tabular}{|c|c|c|c|c|c|c|c|c|}
\hline \multirow{3}{*}{ Fungal Strains } & \multicolumn{6}{|c|}{$\beta$-Galactosidase Activity ${ }^{1}$} & \multirow{3}{*}{$\begin{array}{l}\text { Cultivation } \\
\text { Temperature } \\
\left({ }^{\circ} \mathrm{C}\right)\end{array}$} & \multirow{3}{*}{ Source } \\
\hline & \multicolumn{6}{|c|}{$t($ incubation)/day } & & \\
\hline & 1 & 2 & 4 & 6 & 8 & 10 & & \\
\hline $\begin{array}{c}\text { Lichtheimia ramosa SZMC }{ }^{2} \\
11360\end{array}$ & +++ & +++++ & +++++ & +++++ & +++++ & +++++ & 37 & soil/unknown \\
\hline $\begin{array}{c}\text { Lichtheimia corymbifera } \\
\text { SZMC } 11361\end{array}$ & ++ & ++++ & ++++ & +++++ & +++++ & +++++ & 37 & soil/Afghanistan \\
\hline $\begin{array}{l}\text { Lichtheimia hyalospora } \\
\text { SZMC } 11364\end{array}$ & ++ & ++++ & ++++ & +++++ & +++++ & +++++ & 37 & $\begin{array}{c}\text { Manihot esculenta } \\
\text { stem/Ghana }\end{array}$ \\
\hline $\begin{array}{c}\text { Rhizomucor miehei SZMC } \\
11005\end{array}$ & ++ & +++ & ++++ & ++++ & ++++ & +++++ & 37 & $\begin{array}{l}\text { peppermint } \\
\text { compost/India }\end{array}$ \\
\hline $\begin{array}{c}\text { Rhizomucor miehei SZMC } \\
11014\end{array}$ & ++ & ++++ & +++++ & +++++ & +++++ & +++++ & 37 & compost/Switzerland \\
\hline $\begin{array}{c}\text { Rhizomucor pusillus SZMC } \\
11025\end{array}$ & + & +++ & +++ & ++++ & ++++ & +++++ & 37 & $\begin{array}{c}\text { dead fallen } \\
\text { leaves/California, USA }\end{array}$ \\
\hline $\begin{array}{l}\text { Rhizopus microsporus var. } \\
\text { oligosporus SZMC } 13619\end{array}$ & $\mathrm{NC}$ & + & +++ & ++++ & ++++ & +++++ & 37 & tempeh/Indonesia \\
\hline $\begin{array}{l}\text { Mortierella echinosphaera } \\
\text { SZMC } 11251\end{array}$ & + & + & +++ & ++++ & ++++ & +++++ & 20 & begonia/Netherlands \\
\hline $\begin{array}{l}\text { Umbelopsis longicollis } \\
\text { SZMC } 11208\end{array}$ & + & +++ & ++++ & +++++ & +++++ & +++++ & 25 & soil/Australia \\
\hline $\begin{array}{c}\text { Umbelopsis ramanniana var. } \\
\text { angulispora SZMC } 11234\end{array}$ & + & +++ & +++++ & +++++ & +++++ & +++++ & 25 & unknown/Russia \\
\hline
\end{tabular}

\section{2. $\beta$-Galactosidase Production}

Strains that showed the best $\beta$-galactosidase activity in the screening tests (Table 1 ) were selected for fermentation assays. Both SmF and SSF conditions were carried out to investigate the enzyme production of the selected strains. Two approaches were used in the SmF experiments, in which the effect of the presence of lactose and wheat bran on extracellular $\beta$-galactosidase production yield was monitored. The SSF system consisted of wheat bran and soy flour dry matter moistened with distilled water. 


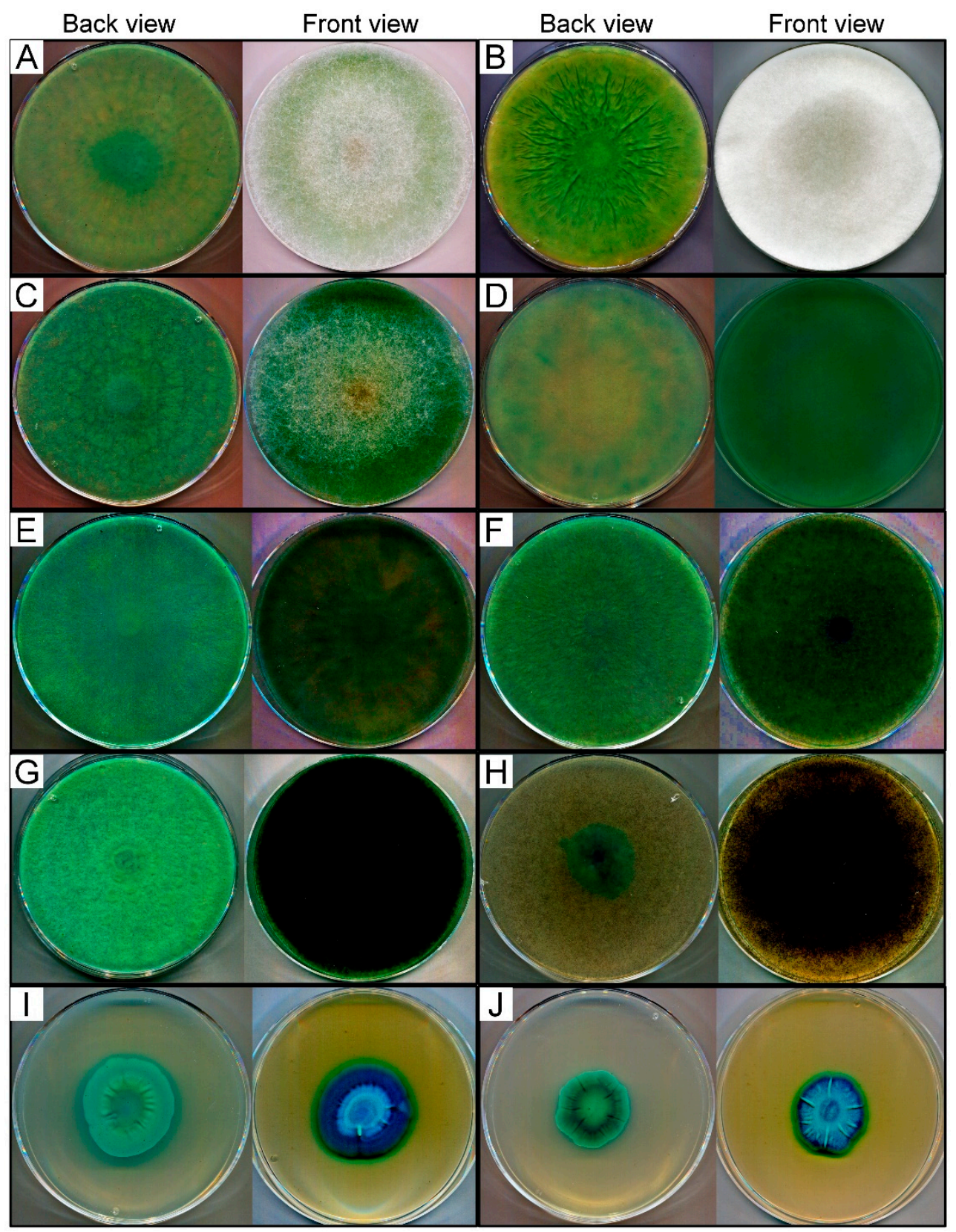

Figure 1. Colonies of L. corymbifera SZMC 11361 (A), L. hyalospora SZMC 11364 (B), L. ramosa SZMC 11360 (C), M. echinosphaera SZMC 11251 (D), R. miehei SZMC 11005 (E), R. miehei SZMC 11014 (F), R. pusillus SZMC 11025 (G), R. microsporus var. oligosporus SZMC 13619 (H), U. longicollis SZMC 11208 (I) and U. ramanniana var. angulispora SZMC 11234 (J) Mucoromycota strains grown on X-gal-containing medium. Experiments were performed on malt extract medium $(20 \% \mathrm{v} / \mathrm{v}$ malt extract, $20 \mathrm{~mL} / \mathrm{L}$; lactose, $20 \mathrm{~g} / \mathrm{L}$; peptone, $1 \mathrm{~g} / \mathrm{L}$; agar, $20 \mathrm{~g} / \mathrm{L}$ ) containing $0.5 \%$ (v/v) X-gal solution. Data were recorded at the 10 th day of cultivation.

Figure 2 depicts the best volumetric $(\mathrm{U} / \mathrm{mL}$ medium or crude extract) and specific ( $\mathrm{U} / \mathrm{mg}$ protein) activity yields achieved during the fermentations. The weight of fungal biomass in wheat bran-contained systems could not be estimated due to separation difficulties of mycelia from the culture flasks. For comparison, specific activity data were considered and refers to the protein concentration in both the culture broths and the crude extracts. 
A

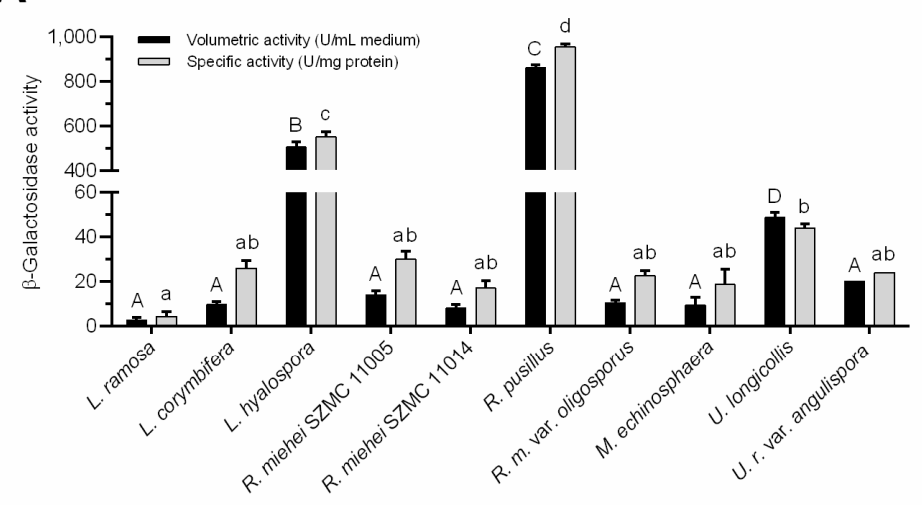

B

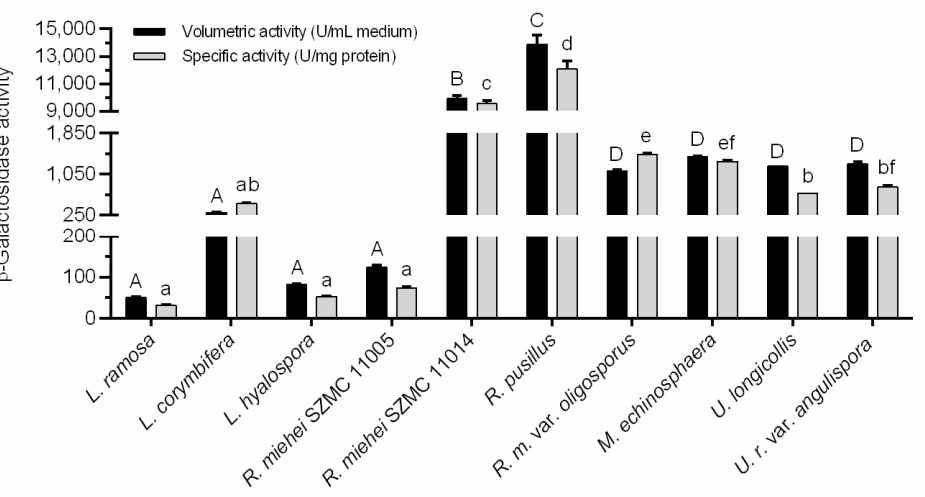

C

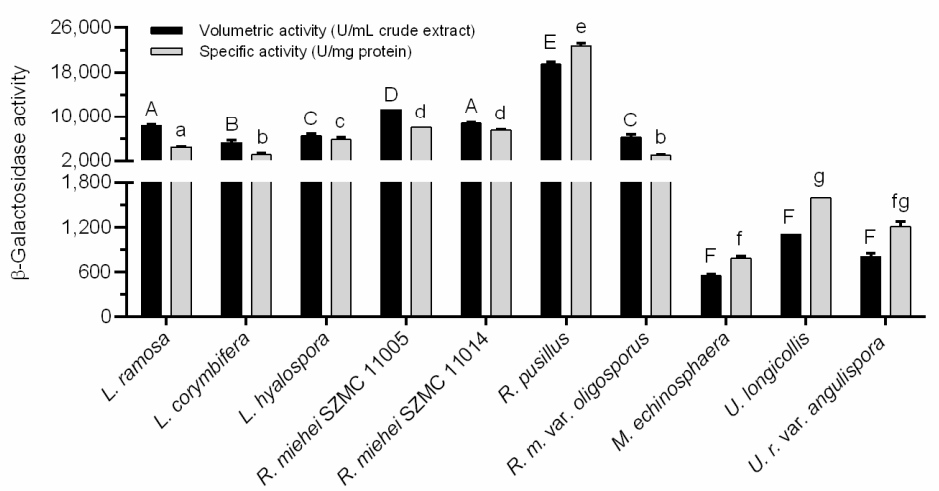

Figure 2. Comparative evaluation of best $\beta$-galactosidase yields (volumetric and specific activities) achieved with $\beta$-galactosidase-producing Mucoromycota fungi under different fermentation conditions. (A) Submerged fermentation (SmF) with medium containing $20 \mathrm{~g} / \mathrm{L}$ lactose. Presented activities were measured on the 2 nd day of incubation by L. ramosa, L. corymbifera, R. miehei, R. microsporus var. oligosporus and $U$. ramanniana var. angulispora, 4 th day by $R$. pusillus and 7 th day by L. hyalospora, M. echinosphaera and U. longicollis. (B) SmF with medium containing $20 \mathrm{~g} / \mathrm{L}$ lactose and wheat bran. Presented activities were recorded on the 7th day except for $R$. microsporus var. oligosporus (2nd day) and L. corymbifera, L. hyalospora, M. echinosphaera and U. longicollis (4th day). (C) Wheat bran-based solid-state fermentation (SSF). Presented activities were determined on the 7th day of fermentation except for $M$. echinosphaera, $U$. longicollis and $U$. ramanniana var. angulispora (4th day). The cultivation temperature was $20^{\circ} \mathrm{C}$ for M. echinosphaera, $25^{\circ} \mathrm{C}$ for U. longicollis and U. ramanniana var. angulispora, and $37^{\circ} \mathrm{C}$ for L. ramosa, L. corymbifera, L. hyalospora, R. miehei, R. pusillus and R. microsporus var. oligosporus. Values are averages computed from three replicates; error bars represent standard deviation. The different uppercase letters (within volumetric activity) or lowercase letters (within specific activity) above the columns indicate significant differences according to one-way ANOVA followed by Tukey's multiple comparison test $(p<0.05)$. 
Overall, the activity data varied between fungus-to-fungus and the $\beta$-galactosidase producing abilities differed according to the applied fermentation system. In lactose supplemented SmF medium, for instance, the U. longicollis, L. hyalospora and R. pusillus exhibited the highest volumetric activity with 48,505 and $860 \mathrm{U} / \mathrm{mL}$ medium mean enzyme yields, respectively (Figure 2A). The $R$. miehei SZMC 11005 and $U$. ramanniana var. angulispora were less active $(p<0.05)$ with moderate volumetric activity yields of 14 and $20 \mathrm{U} / \mathrm{mL}$ medium, respectively. Even less activity was registered for the other fungi tested in this condition (Figure 2A). Concerning the specific activity, however, only the L. hyalospora and R. pusillus displayed outstanding $(p<0.05) \beta$-galactosidase production (yields of 551 and $954 \mathrm{U} / \mathrm{mg}$ protein, respectively) among the tested fungi under this condition (Figure $2 \mathrm{~A})$. The $U$. longicollis exhibited a less specific activity $(44 \mathrm{U} / \mathrm{mg}$ protein) that was not significantly $(p>0.05)$ different from the other tested fungi (Figure $2 \mathrm{~A})$.

The addition of wheat bran to the lactose-containing SmF medium greatly supported the $\beta$-galactosidase production yields. In general, both the volumetric and the specific activities increased by about 10-100 times as compared to the system containing lactose as the sole inducer. It is worth mentioning that a 1,000-fold increase was observed in the case of the R. miehei SZMC 11014 isolate (see Figure 2A,B). Interestingly, the activity of L. hyalospora in this SmF system reduced by about four times to that measured in SmF containing only lactose. Anyway, enzyme activity of the Lichtheimia and the R. miehei SZMC 11005 isolates remained moderate in this condition compared to the other tested fungi $(p<0.05)$. The $\beta$ galactosidase yield detected for these strains ranged between 50 and $303 \mathrm{U} / \mathrm{mL}$ medium, which indicates an efficient induction of enzyme production (Figure 2B). The highest activity yields obtained in this condition were 9,926 and $13,874 \mathrm{U} / \mathrm{mL}$ medium, which was exhibited by the R. miehei SZMC 11014 and R. pusillus isolates, respectively (Figure 2B). Interestingly, enzyme production of the former strain was among the lowest in the system containing lactose as the sole inducer. R. pusillus, however, showed high enzyme yield in that fermentation experiment (Figure 2A). The tested R. microsporus var. oligosporus, M. echinosphaera and the two Umbelopsis isolates did not show any significant difference in their volumetric activities $(p>0.05)$. In contrast, $R$. microsporus var. oligosporus and M. echinosphaera resulted in significantly higher specific activity compared to the Umbelopsis isolates $(p<0.05)$. The maximum $\beta$-galactosidase activities of these strains were found to be varying between 1109 and $1387 \mathrm{U} / \mathrm{mL}$ medium (from 675 to $1436 \mathrm{U} / \mathrm{mg}$ protein) (Figure 2B).

For most fungi tested, cultivation in the wheat bran-based SSF system further improved the $\beta$-galactosidase yields obtained during the two SmFs. Namely, the SSF resulted in a more than 50-fold and 100-fold increase in the volumetric and specific activities, respectively, for L. ramosa, L. hyalospora and R. miehei SZMC 11005 isolates compared to those measured in wheat bran-supplemented SmF (see Figure 2B,C). In this context, elevated specific activity yields were also registered for the other tested strains, except for the M. echinosphaera and R. miehei SZMC 11014, but to a lesser extent than those observed for the above fungi. For $U$. longicollis and $U$. ramanniana var. angulispora, the volumetric activity was slightly higher (1202 and $1248 \mathrm{U} / \mathrm{mL}$, respectively) in wheat bran-based SmF to that achieved in SSF (1109 and $806 \mathrm{U} / \mathrm{mL}$, respectively). Anyway, in SSF, the overall enzyme production of Lichtheimia, Rhizomucor and Rhizopus fungi was superior to those of the Umbelopsis and Mortierella isolates. As in the two SmF tests, R. pusillus exhibited the best activity during SSF, reaching maximal volumetric and specific activity yields of $19,448 \mathrm{U} / \mathrm{mL}$ crude extract and 22,720 U/mg protein, respectively (Figure 2C). Considering the amount of wheat bran substrate subjected to fermentation, the maximal $\beta$-galactosidase activities ranged from 3308 to 116,690 U/g substrate (Figure 3). 


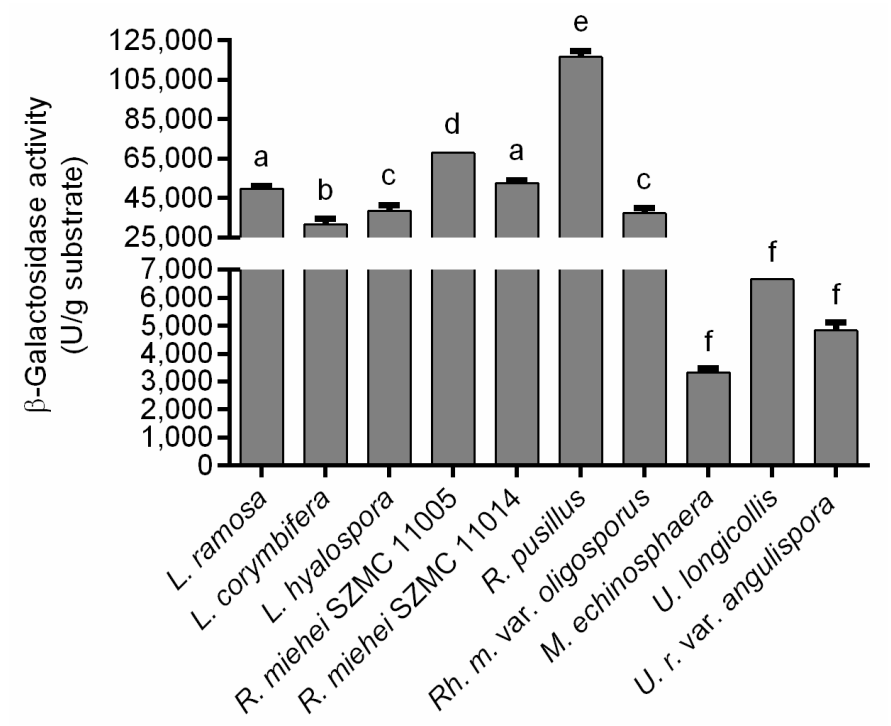

Figure 3. $\beta$-Galactosidase activity (in U/g substrate) of Mucoromycota in wheat bran-based SSF. Presented activities were determined on the 7th day of fermentation except for M. echinosphaera, $U$. longicollis and $U$. ramanniana var. angulispora (4th day). The cultivation temperature was $20^{\circ} \mathrm{C}$ for M. echinosphaera, $25^{\circ} \mathrm{C}$ for $U$. longicollis and $U$. ramanniana var. angulispora, and $37^{\circ} \mathrm{C}$ for L. ramosa, L. corymbifera, L. hyalospora, R. miehei, R. pusillus and R. microsporus var. oligosporus. Values are averages computed from three replicates; error bars represent standard deviation. The different letters above the columns indicate significant differences according to one-way ANOVA followed by Tukey's multiple comparison test $(p<0.05)$.

\subsection{Synthesis of Oligosaccharides}

The oligosaccharide synthesis capacity of $\beta$-galactosidase-active cocktails from $L$. ramosa and R. pusillus obtained on wheat bran-based SSF was also studied. Four sets of conditions were applied in a parallel experiment, each containing different compounds as the glycosyl donor and/or acceptor. Namely, lactose, skim milk, lactose-fructose and oNPG-sucrosebased mixtures were prepared and incubated with or without the corresponding enzyme under a standard condition $\left(50{ }^{\circ} \mathrm{C}, 12 \mathrm{~h}\right)$. Before the reactions were compiled, the $\beta$ galactosidase ferments were purified to eliminate the saccharides and other compounds, which could interfere with the product detection. Protein cocktails with $\beta$-galactosidase activity of $6233 \pm 139 \mathrm{U}$ for L. ramosa and $11,954 \pm 113 \mathrm{U}$ for R. pusillus were successfully prepared through the gel filtration approach used in the study. The protein composition of the cocktails was also analyzed. SDS-PAGE detected protein bands with molecular weights ranging from 15 to $90 \mathrm{kDa}$ and from 27 to $90 \mathrm{kDa}$ in L. ramosa and R. pusillus samples, respectively (Figure S1). Crude $\beta$-galactosidases corresponded to $2400 \mathrm{U}$ activity were introduced to each reaction mixture, and after the incubation, the formation of oligosaccharides was examined via the HPLC MS/MS technique.

Analytical measurements detected oligosaccharides under all reaction conditions, which proved the synthetic activity of the crude L. ramosa and R. pusillus $\beta$-galactosidases. The amount of tri- and tetrasaccharides obtained and the oligosaccharide yield are summarized in Table 2. It shows that the condition based on $o$ NPG-sucrose initial material resulted in the highest oligosaccharide concentrations and the overall synthetic capacity of the $R$. pusillus crude $\beta$-galactosidase were superior to those measured for the L. ramosa enzyme. 
Table 2. Concentration and yield of oligosaccharides obtained with L. ramosa and R. pusillus $\beta$-galactosidase extracts (about 2400 units) on different initial materials.

\begin{tabular}{|c|c|c|c|c|}
\hline \multirow{2}{*}{$\begin{array}{c}\text { Initial } \\
\text { Materials }\end{array}$} & \multirow{2}{*}{ Crude $\beta$-Galactosidase Used } & \multicolumn{2}{|c|}{ Oligosaccharide Concentration $(\mathrm{mg} / \mathrm{L})^{1}$} & \multirow{2}{*}{ Oligosaccharide Yield (\%) ${ }^{2}$} \\
\hline & & Trisaccharide & Tetrasaccharide & \\
\hline \multirow{2}{*}{ Lactose } & L. ramosa & $129.5 \pm 10.7$ & $34.5 \pm 1.1$ & 0.11 \\
\hline & R. pusillus & $197.2 \pm 2.5$ & $60.4 \pm 3.8$ & 0.17 \\
\hline \multirow{2}{*}{ Skim milk } & L. ramosa & $14.4 \pm 0.5$ & $1.4 \pm 0.03$ & 0.032 \\
\hline & R. pusillus & $20.1 \pm 0.02$ & $2.62 \pm 0.02$ & 0.047 \\
\hline \multirow{2}{*}{ Lactose-fructose } & L. ramosa & $88.6 \pm 5.9$ & $18.7 \pm 0.4$ & 0.11 \\
\hline & R. pusillus & $187.6 \pm 5.4$ & $52.2 \pm 3.1$ & 0.24 \\
\hline \multirow{2}{*}{ oNPG-sucrose } & L. ramosa & $856.5 \pm 16.5$ & $48.1 \pm 2.1$ & 0.91 \\
\hline & R. pusillus & $2,040.1 \pm 36.8$ & $196.2 \pm 3.4$ & 2.24 \\
\hline
\end{tabular}

${ }^{1}$ Reactions were carried out at $50{ }^{\circ} \mathrm{C}$ for $12 \mathrm{~h}$ in $50 \mathrm{mM}$ of sodium acetate buffer (pH 6.0) contained $15 \%(w / v)$ lactose, $10 \%(w / v)$ skim milk, $10 \%(w / v)$ lactose +TABLE10\% $(w / v)$ fructose or $90 \mathrm{mM}$ of $o \mathrm{NPG}+10 \%(w / v)$ sucrose. Average values from three tests \pm standard deviation. ${ }^{2}$ Oligosaccharide yield was calculated using Equation (1) (see method Section 2.8).

Oligosaccharide synthesis reactions on lactose and skim milk were performed to estimate transgalactosidase activity. In this type of reaction, tri- and tetrasaccharide GOS products formed by the transgalactosylation of lactose were identified (Table 2). After $12 \mathrm{~h}$ incubation at $50{ }^{\circ} \mathrm{C}$, the GOS contents on skim milk (with a lactose concentration of $48 \mathrm{~g} / \mathrm{L}$ ) by L. ramosa and R. pusillus enzymes achieved 15.8 and $22.7 \mathrm{mg} / \mathrm{L}$, respectively. When $150 \mathrm{~g} / \mathrm{L}$ of lactose was the initial material and the incubation parameters were the same as for skim milk, the GOS concentrations reached maximums at 164 and $257.6 \mathrm{mg} / \mathrm{L}$ for L. ramosa and R. pusillus $\beta$-galactosidases, respectively.

The synthesis of lactulose, which is the basis of OsLu compounds, was examined in reaction mixtures which contained lactose and fructose as initial sugars. This system contained fructose as the acceptor of galactose to produce lactulose disaccharide. However, no lactulose was identified under the applied reaction conditions. Tests were carried out with $20 \%(w / v)$ initial lactose and fructose concentration as well, but no lactulose was detected even in this system. However, under this condition, about two- and 1.2-fold increases in the trisaccharide concentration were achieved for L. ramosa and R. pusillus crude $\beta$-galactosidases, respectively, as compared to the sample containing $10 \%(w / v)$ of initial substrate (Figure 4). Interestingly, the elevated initial sugar concentration did not affect the amount of tetrasaccharide obtained. The formation of fructo-oligosaccharide (FOS) components, i.e., 1-kestose and nystose, was also monitored. These molecules could not be detected even at initial sugar concentrations of $10 \%$ and $20 \%(w / v)$, and therefore, the resulted oligosaccharides might be the transgalactosylation products of the lactose.

Intermolecular transgalactosylation reactions were also monitored on sucrose as the acceptor and $o$ NPG as the galactose donor molecule. This combination of initial materials also resulted in tri- and tetrasaccharides (Table 2). However, FOS compounds were detected, suggesting the simultaneous action of various enzymatic activities in the crude enzyme cocktails. Namely, the reaction mixtures prepared by enzymatic extracts from L. ramosa and R. pusillus contained the FOS molecules 1-kestose $(6.5 \pm 0.3$ and $100.9 \pm 1.1 \mathrm{mg} / \mathrm{L}$, respectively) and nystose (28.2 \pm 1.1 and $114.2 \pm 1.7 \mathrm{mg} / \mathrm{L}$, respectively). In addition, a trisaccharide product was also obtained with a mass-to-charge ratio $(\mathrm{m} / \mathrm{z})$ of 503.3 in this reaction. Concentrations of this compound were $90.3 \pm 5.4$ and $199.3 \pm 12.7 \mathrm{mg} / \mathrm{L}$ for L. ramosa and R. pusillus crude $\beta$-galactosidases, respectively. 


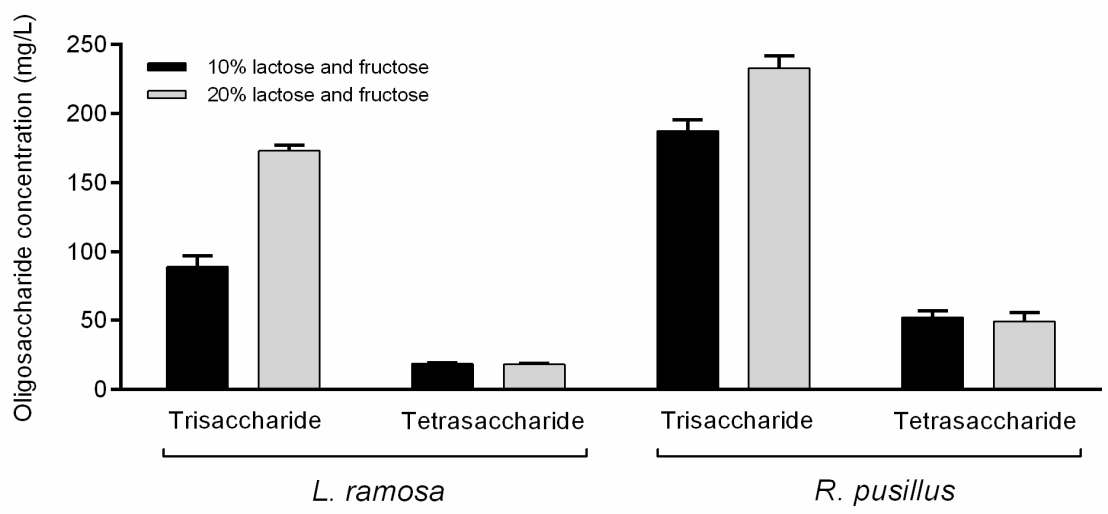

Figure 4. Comparison of oligosaccharide concentrations obtained by L. ramosa and R. pusillus crude $\beta$-galactosidases at $10 \%$ and $20 \%(w / v)$ initial sugar concentrations. The initial sugars were lactose and fructose in mixture. Reactions were performed in a volume of $2 \mathrm{~mL}$ at $50{ }^{\circ} \mathrm{C}$ for $12 \mathrm{~h}$. Values are averages computed from three replicates; error bars represent standard deviation.

\subsection{Growth-Promoting Activity of Synthesized Oligosaccharides}

The effect of oligosaccharide-enriched mixtures produced with both the L. ramosa and the R. pusillus crude $\beta$-galactosidases on the growth of selected probiotic microorganisms was investigated. In this study, the CFU of L. casei, L. acidophilus LA-5, B. animalis subsp. lactis BB-12 and S. boulardii CNCM I-745 was monitored in the presence of reaction samples prepared with initial materials of lactose-fructose, skim milk or lactose. The reaction mixture containing $o \mathrm{NPG}$ as the glycosyl donor was excluded from the experiment due to the potential growth inhibitory effect of the liberating o-nitrophenol. The colony counts were compared to controls, that is, cultures incubated without the addition of reaction samples were considered as Control 1, while Control 2 contained the enzyme-free sample of each reaction mixture. Controls were prepared separately to each cultivation system. After incubation for $24 \mathrm{~h}$, there was no statistically significant difference between the colony counts of the Control 1 and Control 2 (Figure 5A-D), which means that the enzyme-free reaction mixture alone, regardless of the initial sugars, did not affect the bacterial growth.

For most tests, the oligosaccharide-enriched samples stimulated the bacterial growth as compared to the corresponding controls. In L. casei, for instance, the colony count analysis showed a 1.02 to 1.03 times increase in CFU after incubation with enzyme treated samples $(p<0.05)$ (Figure 5A). The highest growth-promoting effect to L. casei was observed for oligosaccharide-containing samples obtained on lactose-fructose initial sugars. The overall colony count in these treated cultures was $8.73 \log \mathrm{CFU} / \mathrm{mL}$, while it was about $8.48 \log \mathrm{CFU} / \mathrm{mL}$ for the controls (Figure 5A). In the case of L. acidophilus, the highest increase in the colony count was 1.08-fold (from 6.28 to $6.77 \log \mathrm{CFU} / \mathrm{mL}$ ) compared to the control $(p<0.05)$ and it was registered for enzyme-treated samples containing skim milk as the initial sugar source (Figure 5B). Lactose-fructose systems treated by L. ramosa or R. pusillus enzymes, as well as the R. pusillus-supplemented lactose-based solution significantly promoted the L. acidophilus growth $(p<0.05)$. Additionally, all enzyme-containing samples significantly $(p<0.05)$ increased the count of $B$. animalis subsp. lactis colonies compared to the controls (Figure 5C). Concerning S. boulardii, the addition of a GOS-enriched mixture obtained on skim milk did not affect the colony count compared to the control samples (Figure 5D). When the enzyme treated samples containing lactose or lactose-fructose initial sugars were applied as additives, however, an increase in the colony count was observed. Among the reaction mixtures tested, the sample prepared on lactose-fructose initial sugars with $R$. pusillus crude $\beta$-galactosidase exhibited the highest growth-supporting activity to S. boulardii (from 6.57 to $6.91 \log \mathrm{CFU} / \mathrm{mL} ; p<0.05$ ) (Figure 5D).

Further analysis of the colony count data as correlated with the trisaccharide and tetrasaccharide concentrations obtained in each saccharide synthesis assay (see Section 3.3) revealed a correlation between the growth-supporting activity of reaction mixtures and 
the amount of these oligosaccharides after the treatment with the crude $\beta$-galactosidase cocktails. This was strongly positive $(r>0.900)$ in L. acidophilus and B. animalis subsp. lactis for both tri- and tetrasaccharide contents found in all reaction samples (Table 3). Similar association $(r>0.900)$ was observed by L. casei and S. boulardii for both tri- and tetrasaccharide amounts obtained on lactose, and by $S$. boulardii for trisaccharide contents obtained on skim milk and lactose-fructose initial materials. Positive $(0.800<r<0.900)$ and moderate $(0.600<r<0.800)$ relationships of some studied variables were identified for S. boulardii and L. casei probiotics, respectively (Table 3 ).

A

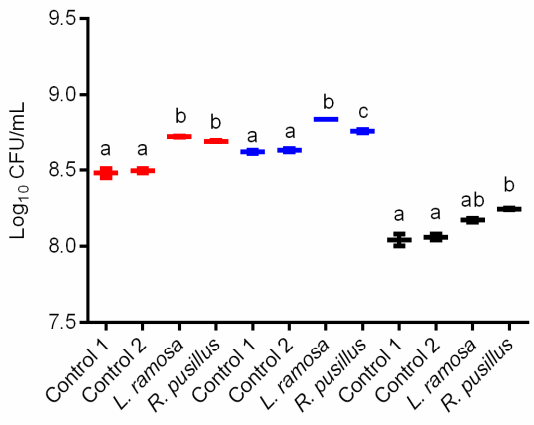

C

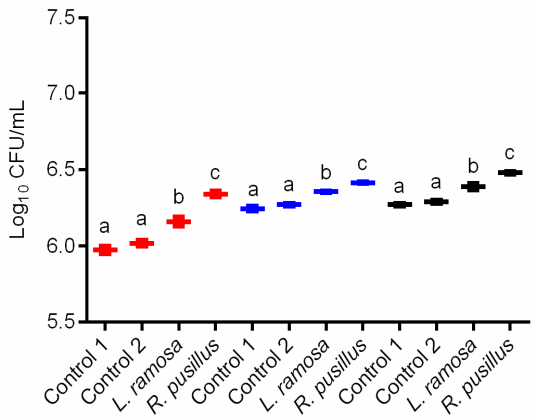

B

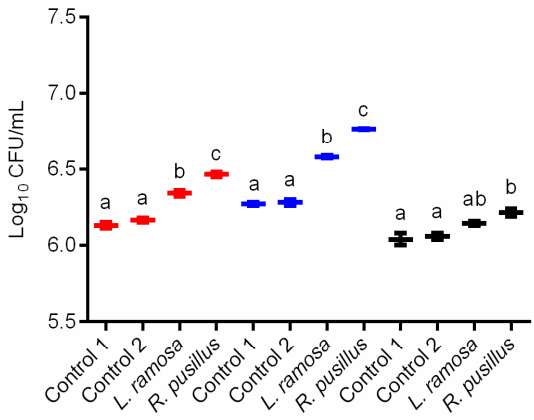

D

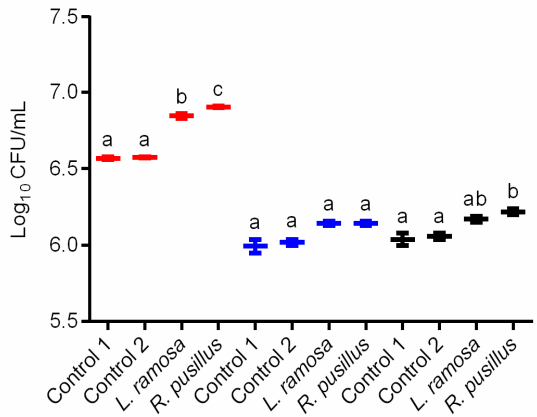

Figure 5. Effect of oligosaccharide-enriched solutions on the growth of L. casei (A), L. acidophilus LA-5 (B), B. animalis subsp. lactis BB-12 (C) and S. boulardii CNCM I-745 (D) probiotic microorganisms. Solutions were produced with $L$. ramosa and R. pusillus partially purified $\beta$-galactosidase-active cocktails on lactose-fructose (red), skim milk (blue) or lactose (black) initial sugar substrates. The colony number counted in the absence of the given solution was taken as Control 1, while Control 2 contained the enzyme-free sample of the corresponding reaction mixture. Presented results are means of three replicates; error bars represent standard deviations. Different letters indicate statistical differences between the controls and the corresponding treatments $(p<0.05)$.

Table 3. Correlation coefficients (Pearson $r$ ) between growth-promoting activity towards different probiotics and total tri- or tetrasaccharide content achieved on each initial material after enzymatic treatments with crude $\beta$-galactosidase cocktails.

\begin{tabular}{ccccc}
\hline Initial Materials & L. casei & L. acidophilus & B. animalis subsp. lactis & S. boulardii \\
\hline Lactose & & & & 0.979 \\
Trisaccharide & 0.991 & 0.985 & 0.999 & 0.999 \\
Tetrasaccharide & 0.998 & 0.999 & & 0.988 \\
Skim milk & & & 0.994 & 0.961 \\
Trisaccharide & 0.791 & 0.995 & 0.993 & 0.875 \\
Tetrasaccharide & 0.635 & 0.992 & & 0.926 \\
Lactose-fructose & & & 0.999 & 0.869 \\
Trisaccharide & 0.785 & 0.986 & 0.989 & \\
Tetrasaccharide & 0.698 & 0.957 & &
\end{tabular}




\section{Discussion}

$\beta$-Galactosidases are important biocatalysts in the food industry where both the hydrolytic and the synthetic activities can be utilized. Although the production and the activity of $\beta$-galactosidases are well characterized in many microorganisms [9], a comprehensive analysis for Mucoromycota has not yet been performed. The current study demonstrates $\beta$-galactosidase producers among Mucorales and Mortierellales, inductive conditions for high-yield enzyme production, as well as the oligosaccharide synthesis capacity of selected Mucoromycota biocatalysts on various initial materials. In addition, the growth-promoting activity of oligosaccharide-enriched cocktails towards probiotics was also evaluated.

In screening assays, $\beta$-galactosidase production of 99 isolates from the genera Rhizomucor, Rhizopus, Lictheimia, Umbelopsis, Mortierella and Mucor was investigated through a chromogenic agar test. The results showed hydrolysis of X-gal by 66 strains, most of which belong to the Rhizomucor, Lichtheimia and Umbelopsis groups. There were five R. microsporus strains with notable activity in the Rhizopus group, and one isolate of M. echinosphaera and M. globulifera with promising $\beta$-galactosidase production were identified among Mortierella. It is worth mentioning that the same M. echinosphaera was found to be an excellent producer of a lipase with transesterification activity in our previous research [25]. The combined application of $\beta$-galactosidases and lipases can result in sugar-lactate copolymer biomaterials under appropriate conditions [26] and the possibility to utilize the two biocatalysts from a same organism is a particularly ecofriendly way. Within the Mucor group, M. circinelloides and M. plumbeus isolates presented the highest activity level. Some $\beta$-galactosidase producers have already been reported from the genera Rhizopus, Rhizomucor and Mucor [12,27,28], however, as far as we know, there were no data concerning Lichtheimia, Mortierella and Umbelopsis species. In filamentous fungi, the enzyme production of Aspergillus, Penicillium and Trichoderma species was studied in detail, and several producers have been identified during recent research studies [12,29-32]. Commercial $\beta$-galactosidases from filamentous fungal sources, especially from Aspergillus, were also previously prepared [33].

The yield of microbial $\beta$-galactosidase production can be increased by using culture conditions supplemented with different inductors. For instance, there were applications of skim milk, lactose, whey, and many agro-industrial substrates as additives to improve the enzyme yield in fungi $[19,29,30,34]$. In our study, the extractable $\beta$-galactosidase activity of ten producers selected following the screen tests (Table 1) was further analyzed in SmF and SSF systems containing lactose and/or wheat bran substrates as inducers for the enzyme production. Differences in $\beta$-galactosidase activities were more detectable in this assay than on X-gal medium. In all fermentation systems, R. pusillus demonstrated the highest volumetric and specific activities, but there were noticeable activity yields for Lichtheimia in SSF (from 3088 to $5793 \mathrm{U} / \mathrm{mg}$ protein) and for R. microsporus var. oligosporus, M. echinosphaera and the two Umbelopsis isolates tested (from 675 to $1436 \mathrm{U} / \mathrm{mg}$ protein) in wheat bran-supplemented SmF conditions. Additionally, both R. miehei strains proved to be good producers in the SSF system (about $7800 \mathrm{U} / \mathrm{mg}$ protein). Comparing the results of wheat bran-based fermentations, most of the maximal enzyme yields were achieved under the solid culture condition. However, M. echinosphaera and R. miehei SZMC 11014 presented slightly more activities in the wheat bran-based SmF than in SSF. Moreover, the SmF resulted in more volumetric activity yields for Umbelopsis than SSF. The different $\beta$-galactosidase activities measured in the SSF and SmF environment can be attributed to several reasons. For instance, the enzyme may be trapped in the cell wall under the SmF condition, while it is secreted to the medium in SSF systems, as it can be observed for other fungal hydrolases [35]. Furthermore, the thermostability of the enzyme can also be different depending on the producing environment applied [36]. It is also well known that culturing in SSF is close to natural growth conditions for filamentous fungi, in which the expression of hydrolytic enzymes is generally more supported [37].

Wheat bran is an inductive substrate for the growth and industrial enzyme production of filamentous fungi both in SSF and SmF conditions [38], which may be responsible for 
the higher $\beta$-galactosidase activity measured in wheat bran-containing media compared to lactose-based systems. The property of wheat bran to enhance the $\beta$-galactosidase production yield has been documented for other filamentous fungi. For instance, optimized yields were reached for Aspergillus tubingensis (15,936 U/g substrate) [18], Penicillium canescens (5292 U/g substrate) [39], and Trichoderma sp. (2.67 U/g substrate) [31] in SSF systems, and for Trichoderma reesei $(25.43 \mathrm{U} / \mathrm{mL})$ [40], Aspergillus niger (from 0.279 to $0.764 \mathrm{U} / \mathrm{mL}$ ) [41] and Aspergillus flavus (843.75 U/mg protein) [42] in SmF systems.

Table 4 summarizes Mucoromycota fungi studied so far in terms of their $\beta$-galactosidase production. As seen, lactose was a commonly studied substrate for the production and the yields reported were generally comparable to those reached in our experiments (Figure 2A). The enzyme activity of Rhizomucor were tested in wheat bran-based SSF (Table 4). However, as we know, there were no $\mathrm{SmF}$ studies so far that used lactose and wheat bran together as a $\beta$-galactosidase inducer. Collectively, it can be concluded that wheat bran is an ideal substrate to induce the $\beta$-galactosidase production in Mucoromycota. The volumetric and specific activity data obtained in our study (Figure 2B,C) are significant compared to those of other Mucoromycota $\beta$-galactosidases presented previously (Table 4 ).

Table 4. $\beta$-Galactosidase production of Mucoromycota, applied fermentation conditions, growth substrates, and the enzyme activity achieved.

\begin{tabular}{ccccc}
\hline Mucoromycota Fungi & Fermentation Condition & Substrate & Enzyme Activity & Reference \\
\hline Mucor sp. & $\mathrm{SmF}^{1}$ & lactose & $228 \mathrm{U} / \mathrm{L}$ & {$[12]$} \\
\hline Rhizomucor sp. & $\mathrm{SmF}^{2}$ & $\begin{array}{c}\text { lactose } \\
\text { wheat bran }\end{array}$ & $\begin{array}{c}0.55 \mathrm{U} / \mathrm{mL}(0.21 \mathrm{U} / \mathrm{mg}) \\
5.5 \mathrm{U} / \mathrm{mL}(2.04 \mathrm{U} / \mathrm{mg})\end{array}$ & {$[14]$} \\
\hline Rhizomucor pusillus & $\mathrm{SSF}^{2}$ & lactose & $2.14 \mathrm{IU} / \mathrm{mL}$ & {$[16]$} \\
\hline Rhizomucor pusillus & $\mathrm{SmF}$ & wheat bran & $101.89 \mathrm{U} / \mathrm{gds}$ & {$[17]$} \\
\hline Rhizopus sp. & $\mathrm{SSF}$ & lactose & less than $10 \mathrm{U} / \mathrm{mL}$ & {$[43]$} \\
\hline Rhizopus stolonifer & $\mathrm{SmF}$ & lactose & $2.250 \mathrm{IU}$ & {$[28]$} \\
\hline
\end{tabular}

${ }^{1}$ SmF: submerged fermentation. ${ }^{2}$ SSF: solid-state fermentation.

It is worth mentioning that the incubation temperature $\left(50{ }^{\circ} \mathrm{C}\right)$ used in $\beta$-galactosidase activity assays may not have been optimal for all enzyme activities tested after the fermentation because the tested fungi cultured could have produce $\beta$-galactosidases at different temperature optimum. Nevertheless, it can be emphasized that most of the $\beta$-galactosidase activities showed by $M$. echinosphaera, $U$. longicollis and $U$. ramanniana var. angulispora (growth at 20 or $25^{\circ} \mathrm{C}$ ) were comparable to the activity data measured in other tested fungi (growth at $37^{\circ} \mathrm{C}$ ) (see Figure 2).

The power of $\beta$-galactosidases to catalyze enzymatic synthesis reactions was examined through the formation of oligosaccharides on different substrates used as glycosyl donors and/or acceptors in mixture. Considering that L. ramosa and R. pusillus exhibited a high $\beta$-galactosidase yield and activity during the SSF and the fact that these fungi are important producers of industrial biocatalysts $[13,44-46]$, their enzymes were selected for these experiments. The $\beta$-galactosidases obtained in SSF were partially purified, and the crude enzymes were introduced to lactose, skim milk, lactose-fructose, or $o$ NPG-sucrose containing reaction solutions. It is worth mentioning that protein composition analysis revealed a complex protein pattern for both the L. ramosa and the R. pusillus crude enzyme samples. Identification, purification, and characterization of their $\beta$-galactosidase enzymes are the subject of our future investigations.

The oligosaccharide synthesis capability of Mucoromycota $\beta$-galactosidases is a highly unexplored area. The literature data are available only for a Mucor sp. enzyme, in which authors reported $2 \mathrm{~g} / \mathrm{L}$ and $2.6 \mathrm{~g} / \mathrm{L}$ GOS concentrations after 20-30-h incubation with mixtures of lactose-fructose and lactose-sucrose, respectively [12]. In the present study, the tested enzymes also exhibited transgalactosylation activity and the maximal oligosac- 
charide concentrations ranged between 0.0158 and $2.236 \mathrm{~g} / \mathrm{L}$ under non-optimized reaction conditions with 12-h incubation time.

GOS production was assessed on skim milk and lactose as initial materials. At the end of the incubation, oligosaccharides were formed on both substrates, indicating transgalactosylation action. Trisaccharide was the main product, similar to the findings of Rodriguez-Colinas et al. [47] who used skim milk and lactose initial substrates and a Bacillus circulans $\beta$-galactosidase (Biolactase) catalyst. The moderate oligosaccharide yield achieved on skim milk can be due to the lactose concentration present. However, skim milk may also contain components (e.g., cations) that can affect the activity of $\beta$-galactosidase during the reaction [48]. Anyway, oligosaccharides also appeared in skim milk fermentation, showing the potential of L. ramosa and R. pusillus $\beta$-galactosidases to be applicable in the dairy industry to produce GOS-enriched milk products.

Lactulose and GOS synthesis were studied when the crude L. ramosa and R. pusillus $\beta$-galactosidases were added to a mixture of lactose-fructose. Although oligosaccharide products were observed in this mixture, no lactulose was detected during the reaction at both $10 \%$ and $20 \%(w / v)$ initial lactose-fructose concentrations. It is important to note, however, that the approaches dealing with high-yield lactulose synthesis apply even higher initial lactose and fructose concentrations than those used in our experiments [49-52]. Practically, in our tests, an increase in the initial substrate concentration caused an increase in the trisaccharide amounts detected after the incubation. These molecules, and the tetrasaccharides, were formed by the transgalatosylation of the lactose. In addition, despite the fact that the R. pusillus enzyme resulted in more oligosaccharides than the L. ramosa $\beta$-galactosidase in all reactions performed, the dependence from the initial substrate concentration has markedly been observed for the latter enzyme here. Correlation between the initial lactose content and the resulting GOS yield has been described for many $\beta$ galactosidases. This relationship, however, can be varied from enzyme-to-enzyme and affected by the reaction parameters (e.g., temperature) $[6,8]$.

Oligosaccharide formation was also observed when the crude enzymes were incubated in a mixture of $o$ NPG and sucrose as the initial material. In this reaction, FOS components, i.e., 1-kestose (C18) and nystose (C24), were detected. In the work of Silvério et al. [12] performed on lactose-sucrose sugars, although that was also an unoptimized experiment, FOS synthesis by the Mucor sp. enzyme was not observed, but was described for most of the other fungal catalysts tested (e.g., for Aspergillus, Penicillium and Trametes enzymes). In most cases, 1-kestose has been identified as the main constituent of FOS. Kestose is also an important prebiotic [53] and can be synthesized by the transfructosylation activity of $\beta$-fructofuranosidase (FFase) or fructosyltransferase (FTase) enzymes [54,55]. Accordingly, the crude $\beta$-galactosidase cocktails purified in our study may have the transfructosylation activity that was responsible for the presence of FOSs during reactions with the mixture of $o$ NPG-sucrose. In addition, because nystose is a common indicator sugar of transfructosylation activity $[54,56,57]$, the presence of this compound in the $o$ NPG-sucrose system further strengthens the occurrence of the reaction. Nevertheless, our results highlighted promising transfructosylation action of both the L. ramosa and the R. pusillus enzyme cocktails, that, although we have not yet investigated such enzyme activities, may be attributed to FFase and/or FTase enzymes present. Noticeable FFase or FTase activities have already been reported in zygomycetes, including strains of Rhizopus stolonifer [58], Rhizopus delemar, Amylomyces rouxii [59], R. microsporus [60] and M. circinelloides [61].

The transfructosylation activity may allow the synthesis of additional FOS compounds, such as lactosucrose $\left(4^{\mathrm{G}}-\beta\right.$-D-galactosylsucrose, [62]) depending on the initial sugars. Moreover, certain $\beta$-galactosidases can also synthesize the lactosucrose [63-65]. In our study, analytical assays showed a trisaccharide compound with the same retention time and mass-to-charge ratio $(m / z$ 503.3) of the raffinose in the $o$ NPG-sucrose containing reaction. It is very likely, although a more detailed analysis of the product is needed, that the resulted saccharide is a lactosucrose, or probably an isoraffinose ( $6^{\mathrm{G}}-\beta$-D-galactosylsucrose), or a mixture of these two compounds. These molecules, however, could not be separated by 
the HPLC-MS technique used in this study. With this context, it is worth mentioning that certain studies suggested the complete inability of fungal $\beta$-galactosidases to synthesize lactosucrose by transgalactosylation $[12,66]$. For isoraffinose synthesis via transgalactosylation action, Suyama et al. [67] reported an evidence in the $o$ NPG-sucrose system using $\beta$-galactosidase from Escherichia coli. Finally, in comparison with lactose-sucrose-based systems commonly used for lactosucrose synthesis, glucose can be released only from the sucrose in such oNPG-sucrose approaches used in our study. Thereby, the lower glucose amount in the mixture can reduce its inhibitory effect on carbohydrase activities responsible for FOS synthesis.

The GOS and FOS molecules developed enzymatically can be used as prebiotic fibers in both adults and infants, promoting the activity of beneficial gut microorganisms [5,68]. In further experiments, we examined the growth-promoting potential of the prepared oligosaccharide-enriched mixtures, i.e., those containing lactose-fructose, skim milk or lactose as initial sugars, towards probiotics commonly used as additives in products. The tested L. casei, L. acidophilus, B. animalis subsp. lactis and S. boulardii probiotic microorganisms possess many properties beneficial for human health [69-71], including the action against pathogens [72-74]. The probiotic microorganisms responded to the oligosaccharideenriched mixtures differently, however, in most cases, considerable growth-promoting effect was identified. In this way, prebiotic oligosaccharides may have formed in the reaction systems developed. On the other hand, the activity towards probiotics (Figure 5) was not altered according to the oligosaccharide content (Table 2) of the different reaction systems. Namely, the growth-supporting action of the skim milk-based system was comparable to those documented for lactose-fructose and lactose systems, except for the $S$. boulardii yeast. Skim milk proved to be a good support for the enzymatic (Maxilact $\beta$-galactosidase cocktail) production of oligosaccharides with prebiotic activity in the study of Oh et al. [75]. Comparing the effect of the samples obtained with the R. pusillus and $L$. ramosa crude $\beta$-galactosidases, mixtures prepared with the former biocatalyst generally resulted in a higher colony count than with the latter one. In line with this, correlation analysis revealed the association between the growth-promoting activity and the oligosaccharide content of a given sample. The higher the oligosaccharide content in a reaction sample after the enzyme treatment, the better the growth of probiotic microorganisms investigated in our study. This assumes that the oligosaccharides formed were responsible for the growth-promoting activity of the samples. However, prebiotic activity of the resulting oligosaccharides has not yet been proven by the above examinations. Therefore, our future investigations aim for the purification of the oligosaccharides formed and their use as sole carbohydrate source in fermentations [76].

\section{Conclusions}

Although microbial $\beta$-galactosidases are key catalysts in the bioprocess technology, there is a knowledge gap in terms of the enzyme activity and production in Mucoromycota. In this work, first, $\beta$-galactosidase-producing isolates from the Mucoromycota group were screened according to their X-gal hydrolyzing capacity. The results revealed the highest activities for strains belonging to the genera Rhizomucor, Lichtheimia and Umbelopsis. Next, we evaluated the $\beta$-galactosidase production of ten selected producers under inductive SmF and SSF conditions containing lactose and/or wheat bran as the growth substrate. We confirmed wheat bran as an excellent support for $\beta$-galactosidase production both in SmF and SSF systems. It is worthy to note that any of the fermentation conditions used in this study were not an optimized environment. The optimization of the culturing environment can further improve production yields, that is, the subject of future experiments. According to the enzymatic synthesis test, the L. ramosa and R. pusillus crude $\beta$-galactosidases investigated can synthesize oligosaccharides from lactose, skim milk, lactose-fructose or $o \mathrm{NPG}$-sucrose initial substrates. Moreover, through FOS compounds formed on $o \mathrm{NPG}$-sucrose initial material, we found that the L. ramosa and R. pusillus could also produce enzyme with transfructosylation activity. Finally, we confirmed the 
growth-promoting effect towards commercial probiotics for the oligosaccharide-enriched mixtures obtained in lactose, skim milk and lactose-fructose based conditions. In conclusion, our results provide useful data about the $\beta$-galactosidase producing capacity of Mucoromycota, including the groups of Lichtheimia, Mortierella and Umbelopsis that have not yet been investigated. The isolates with high hydrolytic activity can be reliable sources of $\beta$-galactosidases utilizable in the food industry. Additionally, the synthetic activities identified may contribute to the production of functional oligosaccharide mixtures with a high prebiotic index on appropriate initial sugars and conditions. These sugar cocktails then can be used as additives enhancing the health benefits of products.

Supplementary Materials: The following are available online at https:/ /www.mdpi.com/2309-608 X/7/3/229/s1, Table S1: Mucoromycota strains included in the $\beta$-galactosidase production screening assays and their activity on X-gal contained medium. The intensity of the blue color is proportional with the enzyme activity, Figure S1: SDS-PAGE analysis of the crude $\beta$-galactosidases. Lane 1 and Lane 2 are L. ramosa and R. pusillus partially purified $\beta$-galactosidases, respectively, obtained after filtration through a Bio-Gel P-6 desalting cartridge (Bio-Rad, Hercules, USA). Lane M: SeeBlue Plus2 SDS-PAGE molecular weight standard (Invitrogen, Carlsbad, USA).

Author Contributions: Conceptualization, B.V. and M.T.; methodology, B.V., M.V., A.S. and M.T.; validation, B.V. and M.T.; formal analysis, B.V., M.V. and M.T.; investigation, B.V., M.V., A.S., G.N., C.V. and A.K.; resources, B.V., M.V., G.N., C.V. and T.P.; writing-original draft preparation, B.V. and M.T.; writing-review and editing, M.T., T.P. and C.V.; supervision, M.T.; project administration, M.T. and M.V.; funding acquisition, M.T. and T.P. All authors have read and agreed to the published version of the manuscript.

Funding: This research was funded by the National Research, Development and Innovation Office (NKFI grant FK 134886) and connected to the EU-funded Hungarian projects EFOP-3.6.1-162016-00008 and GINOP-2.3.2-15-2016-00012. A.K. is supported by the ÚNKP-20-4 New National Excellence Program of the ministry for Innovation and Technology from the source of the National Research, Development and Innovation Fund. T.P. is supported by the grants LP2016-8/2016 and the NKFI K131796.

Institutional Review Board Statement: Not applicable.

Informed Consent Statement: Not applicable.

Data Availability Statement: Not applicable.

Acknowledgments: The authors thank Kinga Regina Juhász and Elvira Nacsa-Farkas for their technical help in the screening studies and growth-supporting activity tests.

Conflicts of Interest: The authors declare no conflict of interest.

\section{References}

1. Szilagyi, A.; Ishayek, N. Lactose intolerance, dairy avoidance, and treatment options. Nutrients 2018, 10, 1994. [CrossRef]

2. Saqib, S.; Akram, A.; Halim, S.A.; Tassaduq, R. Sources of $\beta$-galactosidase and its applications in food industry. 3 Biotech 2017, 7, 79. [CrossRef]

3. Lu, L.; Guo, L.; Wang, K.; Liu, Y.; Xiao, M. $\beta$-Galactosidases: A great tool for synthesizing galactose-containing carbohydrates. Biotechnol. Adv. 2020, 39, 107465. [CrossRef]

4. Cardelle-Cobas, A.; Corzo, N.; Olano, A.; Peláez, C.; Requena, T.; Ávila, M. Galactooligosaccharides derived from lactose and lactulose: Influence of structure on Lactobacillus, Streptococcus and Bifidobacterium growth. Int. J. Food Microbiol. 2011, $149,81-87$. [CrossRef]

5. Davani-Davari, D.; Negahdaripour, M.; Karimzadeh, I.; Seifan, M.; Mohkam, M.; Masoumi, S.J.; Berenjian, A.; Ghasemi, Y. Prebiotics: Definition, types, sources, mechanisms, and clinical applications. Foods 2019, 8, 92. [CrossRef]

6. Vera, C.; Córdova, A.; Aburto, C.; Guerrero, C.; Suárez, S.; Illanes, A. Synthesis and purification of galacto-oligosaccharides: State of the art. World J. Microbiol. Biotechnol. 2016, 32, 197. [CrossRef]

7. Panesar, P.S.; Kaur, R.; Singh, R.S.; Kennedy, J.F. Biocatalytic strategies in the production of galacto-oligosaccharides and its global status. Int. J. Biol. Macromol. 2018, 111, 667-679. [CrossRef]

8. Torres, D.P.; Gonçalves, M.D.P.F.; Teixeira, J.A.; Rodrigues, L.R. Galacto-oligosaccharides: Production, properties, applications, and significance as prebiotics. Compr. Rev. Food Sci. Food Saf. 2010, 9, 438-454. [CrossRef] 
9. Anisha, G.S. $\beta$-Galactosidases. In Current Developments in Biotechnology and Bioengineering: Production, Isolation and Purification of Industrial Products, 1st ed.; Pandey, A., Negi, S., Soccol, C.R., Eds.; Elsevier: Amsterdam, The Netherlands, 2017 ; pp. $395-421$.

10. Tokošová, S.; Hronská, H.; Rosenberg, M. Production of galacto-oligosaccharides by commercial preparates of fungal $\beta$ galactosidase. Acta Chim. Slovaca 2015, 8, 101-106. [CrossRef]

11. Bassetto, R.Z.; Cabral, P.S.; Silveira, M.H.L.; Almeida, M.M.; Chiquetto, N.C. Optimization of $\beta$-galactosidase production from Penicillium sp. for synthesis of galactooligosaccharides. Int. Food Res. J. 2017, 24, 1793-1798.

12. Silvério, S.C.; Macedo, E.A.; Teixeira, J.A.; Rodrigues, L.R. New $\beta$-galactosidase producers with potential for prebiotic synthesis. Bioresour. Technol. 2018, 250, 131-139. [CrossRef]

13. Papp, T.; Nyilasi, I.; Csernetics, Á.; Nagy, G.; Takó, M.; Vágvölgyi, C. Improvement of industrially relevant biological activities in Mucoromycotina fungi. In Gene Expression Systems in Fungi: Advancements and Applications. Fungal Biology; Schmoll, M., Dattenböck, C., Eds.; Springer: Cham, Switzerland, 2016; pp. 97-118.

14. Shaikh, S.A.; Khire, J.M.; Khan, M.I. Production of $\beta$-galactosidase from thermophilic fungus Rhizomucor sp. J. Ind. Microbiol. Biotechnol. 1997, 19, 239-245. [CrossRef]

15. Shaikh, S.A.; Khire, J.M.; Khan, M.I. Characterization of a thermostable extracellular $\beta$-galactosidase from a thermophilic fungus Rhizomucor sp. Biochim. Biophys. Acta Gen. Subj. 1999, 1472, 314-322. [CrossRef]

16. Panesar, P.S.; Kaur, R.; Singh, R.S. Isolation and screening of fungal strains for $\beta$-galactosidase production. WASET Int. J. Nutr. Food Eng. 2016, 10, 400-404.

17. Kaur, R.; Panesar, P.S.; Singh, R.S. Utilization of agro-industrial residues for the production of $\beta$-galactosidase using fungal isolate under solid state fermentation conditions. Acta Aliment. 2018, 47, 162-170. [CrossRef]

18. Raol, G.G.; Raol, B.V.; Prajapati, V.S.; Bhavsar, N.H. Utilization of agro-industrial waste for $\beta$-galactosidase production under solid state fermentation using halotolerant Aspergillus tubingensis GR1 isolate. 3 Biotech 2015, 5, 411-421. [CrossRef]

19. Kazemi, S.; Khayati, G.; Faezi-Ghasemi, M. $\beta$-Galactosidase production by Aspergillus niger ATCC 9142 using inexpensive substrates in solid-state fermentation: Optimization by orthogonal arrays design. Iran. Biomed. J. 2016, 20, $287-294$.

20. Panesar, P.S.; Kaur, R.; Singla, G.; Sangwan, R.S. Bio-processing of agro-industrial wastes for production of food-grade enzymes: Progress and prospects. Appl. Food Biotechnol. 2016, 3, 208-227.

21. Sharma, S.; Singh, P. Isolation and characterization of $\beta$-galactosidase enzyme producing microbe and optimization of its enzyme activity under different culture condition. Int. J. Curr. Microbiol. App. Sci. 2014, 3, 148-155.

22. Vidya, B.; Palaniswamy, M.; Gopalakrishnan, V.K. Screening and optimization of $\beta$-galactosidase from fungal strains by using agro residues. World J. Pharm. Sci. 2014, 3, 1809-1821.

23. Torres, J.M.O.; dela Cruz, T.E.E. Production of xylanases by mangrove fungi from the Philippines and their application in enzymatic pretreatment of recycled paper pulps. World J. Microbiol. Biotechnol. 2013, 29, 645-655. [CrossRef]

24. Soren, J.P.; Halder, S.K.; Mondal, J.; Hor, P.K.; Mohapatra, P.K.D.; Mondal, K.C. A permissive approach for optimization of L-glutaminase production using wheat bran as supporting substrate and assessment of its cytotoxic potentialities. Acta Biol. Szeged. 2020, 64, 1-10. [CrossRef]

25. Kotogán, A.; Zambrano, C.; Kecskeméti, A.; Varga, M.; Szekeres, A.; Papp, T.; Vágvölgyi, C.; Takó, M. An organic solvent-tolerant lipase with both hydrolytic and synthetic activities from the oleaginous fungus Mortierella echinosphaera. Int. J. Mol. Sci. 2018, 19, 1129. [CrossRef] [PubMed]

26. Jia, H.; Wang, P. Enzymatic synthesis of galactosyl lactic ethyl ester and its polymer for use as biomaterials. J. Biotechnol. 2007, 132, 314-317. [CrossRef]

27. Ismail, S.A.; Mabrouk, S.S.; Mahoney, R.R. Purification and characterization of $\beta$-galactosidase from Mucor pusillus. J. Food Biochem. 1997, 21, 145-162. [CrossRef]

28. Vishwanataha, T.; Sampath, A.; Jain, S.N.; Divyashree, B.C.; Reena, V.; Sowmya, G.; MohanKumar, B.S.; Venugopal, N.; Patil, S.J.; Siddalingeshwara, K.G. A novel approach for screening and synthesis of $\beta$-galactosidase from microbial origin. Int. J. Appl. Biotechnol. Biochem. 2012, 2, 285-290.

29. Martarello, R.D.; Cunha, L.; Cardoso, S.L.; de Freitas, M.M.; Silveira, D.; Fonseca-Bazzo, Y.M.; Homem-de-Mello, M.; Filho, E.X.F.; Magalhães, P.O. Optimization and partial purification of beta-galactosidase production by Aspergillus niger isolated from Brazilian soils using soybean residue. AMB Express 2019, 9, 81. [CrossRef]

30. Abd El-Salam, B.A.; Ibrahim, O.A.; Amer, A.E. Efficient enzymatic conversion of lactose in milk using fungal $\beta$-galactosidase. Biocatal. Agric. Biotechnol. 2020, 29, 101813. [CrossRef]

31. De Jesus, L.F.M.C.; Guimarães, L.H.S. Production of $\beta$-galactosidase by Trichoderma sp. through solid-state fermentation targeting the recovery of galactooligosaccharides from whey cheese. J. Appl. Microbiol. 2021, 130, 865-877. [CrossRef] [PubMed]

32. Vidya, B.; Palaniswamy, M.; Angayarkanni, J.; Nawaz, K.A.; Thandeeswaran, M.; Chaithanya, K.K.; Tekluu, B.; Muthusamy, K.; Gopalakrishnan, V.K. Purification and characterization of $\beta$-galactosidase from newly isolated Aspergillus terreus (KUBCF1306) and evaluating its efficacy on breast cancer cell line (MCF-7). Bioorg. Chem. 2020, 94, 103442. [CrossRef]

33. Zolnere, K.; Ciprovica, I. The comparison of commercially available $\beta$-galactosidases for dairy industry: Review. In Proceedings of the 23rd Annual International Scientific Conference "Research for Rural Development 2017", Jelgava, Latvia, 17-19 May 2017; Latvia University of Agriculture: Jelgava, Latvia, 2017; Volume 1, pp. 215-222.

34. Kaur, R.; Panesar, P.S.; Singh, R.S. Utilization of whey for the production of $\beta$-galactosidase using yeast and fungal culture. WASET Int. J. Nutr. Food Eng. 2015, 9, 739-743. 
35. Oda, K.; Kakizono, D.; Yamada, O.; Iefuji, H.; Akita, O.; Iwashita, K. Proteomic analysis of extracellular proteins from Aspergillus oryzae grown under submerged and solid-state culture conditions. Appl. Environ. Microbiol. 2006, 72, 3448-3457. [CrossRef] [PubMed]

36. Mateos Diaz, J.C.; Rodríguez, J.A.; Roussos, S.; Cordova, J.; Abousalham, A.; Carriere, F.; Baratti, J. Lipase from the thermotolerant fungus Rhizopus homothallicus is more thermostable when produced using solid state fermentation than liquid fermentation procedures. Enzym. Microb. Technol. 2006, 39, 1042-1050. [CrossRef]

37. Manan, M.A.; Webb, C. Estimation of growth in solid state fermentation: A review. Malays. J. Microbiol. 2018, 14, 61-69.

38. Javed, M.M.; Zahoor, S.; Shafaat, S.; Mehmooda, I.; Gul, A.; Rasheed, H.; Bukhari, A.I.; Aftab, M.N. Wheat bran as a brown gold: Nutritious value and its biotechnological applications. Afr. J. Microbiol. Res. 2012, 6, 724-733.

39. Assamoi, A.A.; Bedikou, M.E.; Soro-Yao, A.A.; Niamke, L.S.; Destain, J.; Thonart, P. $\beta$-Galactosidase production by solid state fermentation of wheat bran/whole wheat without any supplement. World J. Pharm. Pharma. Sci. 2015, 4, $196-207$.

40. Adalberto, P.R.; Massabni, A.C.; Goulart, A.J.; Contiero, J.; Carmona, E.C.; Cardello, L.; Monti, R. Production of $\beta$-galactosidase by Trichoderma reesei FTKO-39 in wheat bran. Appl. Biochem. Biotechnol. 2006, 133, 163-170. [CrossRef]

41. Saburi, W.; Ueno, H.M.; Matsui, H.; Mori, H. Acidophilic $\beta$-galactosidase from Aspergillus niger AHU7120 with lactose hydrolytic activity under simulated gastric conditions. J. Appl. Glycosci. 2014, 61, 53-57. [CrossRef]

42. Patel, J.D.; Raol, B.V.; Bhavsar, N.H.; Raol, G.G. One-factor-at-a-time (OFAT) optimization of $\beta$-galactosidase production from Aspergillus flavus gr. NFCCI-2728 in submerged fermentation. J. Harmoniz. Res. Appl. Sci. 2018, 6, 227-235. [CrossRef]

43. Seyis, I.; Aksoz, N. Production of lactase by Trichoderma sp. Food Technol. Biotechnol. 2004, 42, 121-124.

44. Robledo, A.; Aguilar, C.N.; Belmares-Cerda, R.E.; Flores-Gallegos, A.C.; Contreras-Esquivel, J.C.; Montañez, J.C.; Mussatto, S.I. Production of thermostable xylanase by thermophilic fungal strains isolated from maize silage. CyTA J. Food 2016, 14, 302-308. [CrossRef]

45. Garcia, N.F.L.; da Silva Santos, F.R.; Bocchini, D.A.; da Paz, M.F.; Fonseca, G.G.; Leite, R.S.R. Catalytic properties of cellulases and hemicellulases produced by Lichtheimia ramosa: Potential for sugarcane bagasse saccharification. Ind. Crops Prod. 2018, 122, 49-56. [CrossRef]

46. De Andrade Silva, C.A.; da Silva, P.G.P.; da Silva, G.F.A.; Dantas, D.P.; Leite, R.S.R.; Fonseca, G.G. Biotransformation of fruit residues via solid state bioprocess using Lichtheimia ramosa. SN Appl. Sci. 2020, 2, 861. [CrossRef]

47. Rodriguez-Colinas, B.; Poveda, A.; Jimenez-Barbero, J.; Ballesteros, A.O.; Plou, F.J. Galacto-oligosaccharide synthesis from lactose solution or skim milk using the $\beta$-galactosidase from Bacillus circulans. J. Agric. Food Chem. 2012, 60, 6391-6398. [CrossRef]

48. Fischer, C.; Kleinschmidt, T. Synthesis of galactooligosaccharides in milk and whey: A review. Compr. Rev. Food Sci. Food Saf. 2018, 17, 678-697. [CrossRef]

49. Hua, X.; Yang, R.; Zhang, W.; Fei, Y.; Jin, Z.; Jiang, B. Dual-enzymatic synthesis of lactulose in organic-aqueous two-phase media. Food Res. Int. 2010, 43, 716-722. [CrossRef]

50. Song, Y.S.; Suh, Y.J.; Park, C.; Kim, S.W. Improvement of lactulose synthesis through optimization of reaction conditions with immobilized $\beta$-galactosidase. Korean J. Chem. Eng. 2013, 30, 160-165. [CrossRef]

51. Guerrero, C.; Vera, C.; Serna, N.; Illanes, A. Immobilization of Aspergillus oryzae $\beta$-galactosidase in an agarose matrix functionalized by four different methods and application to the synthesis of lactulose. Bioresour. Technol. 2017, 232, 53-63. [CrossRef]

52. Aburto, C.; Guerrero, C.; Vera, C.; Illanes, A. Improvement in the yield and selectivity of lactulose synthesis with Bacillus circulans $\beta$-galactosidase. LWT Food Sci. Technol. 2020, 118, 108746. [CrossRef]

53. Tochio, T.; Kadota, Y.; Tanaka, T.; Koga, Y. 1-Kestose, the smallest fructooligosaccharide component, which efficiently stimulates Faecalibacterium prausnitzii as well as Bifidobacteria in humans. Foods 2018, 7, 140. [CrossRef]

54. Lorenzoni, A.S.G.; Aydos, L.F.; Klein, M.P.; Rodrigues, R.C.; Hertz, P.F. Fructooligosaccharides synthesis by highly stable immobilized $\beta$-fructofuranosidase from Aspergillus aculeatus. Carbohydr. Polym. 2014, 103, 193-197. [CrossRef]

55. Veana, F.; Flores-Gallegos, A.C.; Gonzalez-Montemayor, A.M.; Michel-Michel, M.; Lopez-Lopez, L.; Aguilar-Zarate, P.; AscacioValdés, J.A.; Rodríguez-Herrera, R. Invertase: An enzyme with importance in confectionery food industry. In Enzymes in Food Technology; Kuddus, M., Ed.; Springer: Singapore, 2018; pp. 187-212.

56. Cunha, J.S.; Ottoni, C.A.; Morales, S.A.V.; Silva, E.S.; Maiorano, A.E.; Perna, R.F. Synthesis and characterization of fructosyltransferase from Aspergillus oryzae IPT-301 for high fructooligosaccharides production. Braz. J. Chem. Eng. 2019, 36, 657-668. [CrossRef]

57. Chaisuwan, W.; Manassa, A.; Phimolsiripol, Y.; Jantanasakulwong, K.; Chaiyaso, T.; Pathom-aree, W.; You, S.; Seesuriyachan, P. Integrated ultrasonication and microbubble-assisted enzymatic synthesis of fructooligosaccharides from brown sugar. Foods $\mathbf{2 0 2 0}$ 9, 1833. [CrossRef]

58. Lateef, A.; Oloke, J.K.; Kana, E.B.G.; Oyeniyi, S.O.; Onifade, O.R.; Oyeleye, A.O.; Oladosu, O.C. Rhizopus stolonifer LAU 07: A novel source of fructosyltransferase. Chem. Pap. 2008, 62, 635-638. [CrossRef]

59. Orikasa, Y.; Oda, Y. Molecular characterization of $\beta$-fructofuranosidases from Rhizopus delemar and Amylomyces rouxii. Folia Microbiol. 2013, 58, 301-309. [CrossRef] [PubMed]

60. Orikasa, Y.; Oda, Y.; Ohwada, T. Identification of sucA, encoding $\beta$-fructofuranosidase, in Rhizopus microsporus. Microorganisms 2018, 6, 26. [CrossRef] 
61. Ojwach, J.; Kumar, A.; Mutanda, T.; Mukaratirwa, S. Fructosyltransferase and inulinase production by indigenous coprophilous fungi for the biocatalytic conversion of sucrose and inulin into oligosaccharides. Biocatal. Agric. Biotechnol. 2020, $30,101867$. [CrossRef]

62. Chen, C.; Deng, J.; Lv, X.; Li, J.; Du, G.; Li, H.; Liu, L. Biocatalytic synthesis of lactosucrose using a recombinant thermostable $\beta$-fructofuranosidase from Arthrobacter sp. 10138. Bioengineered 2020, 11, 416-427. [CrossRef] [PubMed]

63. Villamiel, M.; Montilla, A.; Olano, A.; Corzo, N. Production and bioactivity of oligosaccharides derived from lactose. In Food Oligosaccharides: Production, Analysis and Bioactivity; Moreno, F.J., Sanz, M.L., Eds.; Wiley-Blackwell: Chichester, UK, 2014; pp. 137-167.

64. Duarte, L.S.; da Natividade Schöffer, J.; Lorenzoni, A.S.G.; Rodrigues, R.C.; Rodrigues, E.; Hertz, P.F. A new bioprocess for the production of prebiotic lactosucrose by an immobilized $\beta$-galactosidase. Process Biochem. 2017, 55, 96-103. [CrossRef]

65. Liao, X.; Huang, J.; Zhou, Q.; Guo, L.; Lin, J.; You, L.; Liu, S.; Yang, J. Designing of a novel $\beta$-galactosidase for production of functional oligosaccharides. Eur. Food Res. Technol. 2017, 243, 979-986. [CrossRef]

66. Cardoso, B.B.; Silvério, S.C.; Abrunhosa, L.; Teixeira, J.A.; Rodrigues, L.R. $\beta$-Galactosidase from Aspergillus lacticoffeatus: A promising biocatalyst for the synthesis of novel prebiotics. Int. J. Food Microbiol. 2017, 257, 67-74. [CrossRef] [PubMed]

67. Suyama, K.; Adachi, S.; Toba, T.; Sohma, T.; Hwang, C.J.; Itoh, T. Isoraffinose (6 ${ }^{\mathrm{G}}-\beta$-galactosylsucrose) synthesized by the intermolecular transgalactosylation reaction of Escherichia coli $\beta$-galactosidase. Agric. Biol. Chem. 1986, 50, 2069-2075. [CrossRef]

68. Verkhnyatskaya, S.; Ferrari, M.; de Vos, P.; Walvoort, M.T.C. Shaping the infant microbiome with non-digestible carbohydrates. Front. Microbiol. 2019, 10, 343. [CrossRef] [PubMed]

69. Sheikhi, A.; Shakerian, M.; Giti, H.; Baghaeifar, M.; Jafarzadeh, A.; Ghaed, V.; Heibor, M.R.; Baharifar, N.; Dadafarin, Z.; Bashirpour, G. Probiotic yogurt culture Bifidobacterium animalis subsp. lactis BB-12 and Lactobacillus acidophilus LA-5 modulate the cytokine secretion by peripheral blood mononuclear cells from patients with ulcerative colitis. Drug Res. 2016, 66, 300-305. [CrossRef] [PubMed]

70. Szajewska, H.; Konarska, Z.; Kołodziej, M. Probiotic bacterial and fungal strains: Claims with evidence. Dig. Dis. 2016, 34, 251-259. [CrossRef]

71. Hill, D.; Sugrue, I.; Tobin, C.; Hill, C.; Stanton, C.; Ross, R.P. The Lactobacillus casei group: History and health related applications. Front. Microbiol. 2018, 9, 2107. [CrossRef]

72. Silva, M.P.; Rossoni, R.D.; Junqueira, J.C.; Jorge, A.O.C. Probiotics for prevention and treatment of candidiasis and other infectious diseases: Lactobacillus spp. and other potential bacterial species. In Probiotics and Prebiotics in Human Nutrition and Health; Rao, V., Rao, L.G., Eds.; IntechOpen: London, UK, 2016; pp. 241-262.

73. Invernici, M.M.; Furlaneto, F.A.C.; Salvador, S.L.; Ouwehand, A.C.; Salminen, S.; Mantziari, A.; Vinderola, G.; Ervolino, E.; Santana, S.I.; Silva, P.H.F.; et al. Bifidobacterium animalis subsp. lactis HN019 presents antimicrobial potential against periodontopathogens and modulates the immunological response of oral mucosa in periodontitis patients. PLoS ONE 2020, 15, e0238425. [CrossRef]

74. Pais, P.; Almeida, V.; Yllmaz, M.; Teixeira, M.C. Saccharomyces boulardii: What makes it tick as successful probiotic? J. Fungi 2020, 6, 78. [CrossRef]

75. Oh, N.S.; Kim, K.; Oh, S.; Kim, Y. Enhanced production of galactooligosaccharides enriched skim milk and applied to potentially synbiotic fermented milk with Lactobacillus rhamnosus 4B15. Food Sci. Anim. Resour. 2019, 39, 725-741. [CrossRef]

76. Fara, A.; Sabater, C.; Palacios, J.; Requena, T.; Montilla, A.; Zárate, G. Prebiotic galactooligosaccharides production from lactose and lactulose by Lactobacillus delbrueckii subsp. bulgaricus CRL450. Food Funct. 2020, 11, 5875-5886. [CrossRef] 